\title{
EFFICACY OF BALNEOTHERAPY ON PAIN, FUNCTION AND QUALITY OF LIFE IN PATIENTS WITH CHRONIC LOW BACK PAIN, AND HAND OR KNEE OSTEOARTHRITIS
}

\author{
Ph.D. Thesis
}

ÁGOTA KULISCH, M.D.

Szeged, 2016 


\title{
EFFICACY OF BALNEOTHERAPY ON PAIN, FUNCTION AND QUALITY OF LIFE IN PATIENTS WITH CHRONIC LOW BACK PAIN, AND HAND OR KNEE OSTEOARTHRITIS
}

\author{
Ph.D. Thesis
}

\section{ÁGOTA KULISCH, M.D.}

\author{
Supervisor: \\ Tamás Bender, M.D., Ph.D., D.Sc. \\ University of Szeged, Hungary \\ Faculty of Medicine \\ Department of Orthopedics
}

Director of Doctoral School of Clinical Medicine:

Lajos Kemény, M.D., D.Sc.

PhD programme titled:

Clinical and Experimental Research in Reactivating and Organ-Saving Surgery.

Clinical and experimental investigations into solutions

based on evidence for sustaining and reactivating articular functions

\section{University of Szeged, Hungary \\ Faculty of Medicine \\ Department of Orthopedics}

Szeged, 2016 


\section{LIST OF PUBLICATIONS}

included in the dissertation

I. Kulisch Á, Bender T, Németh A, Szekeres L. Effect of thermal water and adjunctive electrotherapy on chronic low back pain: a double-blind, randomized, follow-up study. J Rehabil Med 2009; 41: 73-9. IF: 1.882

II. Horváth K*, Kulisch Á*, Németh A, Bender T. Evaluation of the effect of balneotherapy in patients with osteoarthritis of the hands: a randomized controlled single-blind follow-up study. Clin Rehabil 2012; 26: 431-441. IF: 2.191

(* Katalin Horváth and Ágota Kulisch contributed equally to this work.)

III. Kulisch Á, Benkő Á, Bergmann A, Gyarmati N, Horváth J, Kránicz Á, Mándó Zs, Matán Á, Németh A, Szakál E, Szántó D, Szekeres L, Bender T.: Evaluation of the effect of Lake Hévíz thermal mineral water in patients with osteoarthritis of the knee: a randomized, controlled, single-blind, follow-up study. Eur J Phys Rehabil Med. 2014; 50(4): 373-81.

\section{IF: 2.060}




\section{LIST OF PUBLICATIONS}

related to the subject of the dissertation

Gyarmati N., Kulisch Á.: History and description of Hévíz spa with special emphasis on weigth-bath. Press. Therm. Climat. 2008; 145: 233-242.

Bender T., Kulisch Á., Kovács Cs., Horváth K., Gyarmati N., Tefner I., K.. A balneoterápia jelentősége az osteológiában. Lege Artis Med. 2012; 22: 655-60.

Kulisch Á., Horváth K., Németh A., Bender T. A balneoterápia és kiegészítő elektroterápia hatásának vizsgálata térdarthrosisban szenvedő betegekre. Balneológia, Gyógyfürdöügy, Gyógyidegenforgalom, XXXIII. Évfolyam 1. szám, Budapest, 2014.

\section{LIST OF PUBLICATIONS}

non related to the subject of the dissertation

Kulisch Á., Fekete S., Osváth P. Öngyilkosságot elkövetõk búcsúleveleinek grafológiai elemzése. Psychiatria Hungarica, 2000, 15 (2): 575-582.

Kulisch Á., Lengyel Zs., Battyáni Z., Szekeres Gy. Sejtproliferáció és apoptózis immunmorfológiai vizsgálata melanóma malignumban.

Bőrgyógyászati és Venerológiai Szemle 2001. 77. évf. 6. 255 - 258.

\section{BOOK CHAPTERS}

Kulisch Ágota, Horváth Katalin, Kovács Csaba. Hidroterápia és hidroterápiás eljárások In: Bender T, szerk. Balneoterápia és hidroterápia.

Budapest, Medicina Könyvkiadó Zrt; 2014: 153-177.

Gyarmati Noémi, Kulisch Ágota, Mándó Zsuzsanna. A balneológia helye az egészségturizmusban. In: Lőke Zs., szerk. Desztinációmenedzsment az egészségturizmusban. Keszthely, Pannon Egyetem Georgikon Kar, Keszthely 2014: 77-107. 


\section{PRESENTATIONS}

related to the subject of the dissertation

Ágota Kulisch, Alice Dalmadi, Magdolna Mózes, Sándor Kertai, György Végh, László Haraszti, Agnes Vathy, Agnes Czimbalmos. The therapeutics effects of Hévíz thermal water in osteoporosis and LBP. (oral presentation) 35 th World Congress of ISMH 2006, Istanbul

Kulisch Ágota, Dalmadi Alice, Mózes Magdolna, Kertai Sándor, Végh György, Haraszti László, Vathy Ágnes, Czimbalmos Ágnes. A hévízi termálvíz hatásának vizsgálata osteoporosisban és krónikus LBP-ben szenvedő betegeken. Magyar Balneológiai Nagygyülés, 2006, Debrecen

Kulisch Ágota, Németh András, Szekeres László, Bender Tamás. The therapeutic effects of Celldömölk thermal water in low back pain.

V. Hungarian-Turkish Balneological Symposium 2007, Hévíz

Kulisch Ágota, Németh András, Szekeres László, Bender Tamás. A celldömölki ásványvíz gyógyhatásának vizsgálata LBP-ben szenvedő betegeken. Kettős vak, randomizált, placebo kontrollált vizsgálat. Magyar Reumatológusok Egyesülete Ifjúsági Fórum 2007, Noszvaj

Kulisch Ágota, Németh András, Szekeres László, Bender Tamás. A celldömölki ásványvíz gyógyhatásának vizsgálata LBP-ben szenvedő betegeken. Kettős vak, randomizált, placebo kontrollált vizsgálat. Magyar Balneológiai Nagygyűlés 2007, Esztergom

Horváth Katalin, Kulisch Ágota, Németh András, Szekeres László, Bender Tamás. A gunarasi termál-ásványvíz gyógyhatásának vizsgálata primér kézarthrosisban szenvedő betegeken. (oral presentation) 37th World Congress of ISMH 2010, Paris

Kulisch Ágota Balneotherapy in Hévíz Conference on „Rehabilitation and wellness services in Hungary". 2010, Vilnius 
Kulisch Ágota, Horváth Katalin, Németh András, Szekeres László, Bender Tamás. A gunarasi termál-ásványvíz gyógyhatásának vizsgálata primér kézarthrosisban szenvedő betegeken Magyar Balneológiai Nagygyülés 2010, Gyula

Kulisch Ágota, Benkő Ágota, Bergmann Annamária, Gyarmati Noémi, Horváth József, Kránicz Ágota, Mándó Zsuzsanna, Matán Ágnes, Németh András, Szakál Erika, Szántó Dóra, Szekeres László, Bender Tamás. A Hévízi-tó termál-ásványvízének vizsgálata primér térdarthrosisban szenvedő betegekre (randomizált, kontrollált, egyszeresen vak, utánkövetéses vizsgálat). Magyar Balneológiai Nagygyülés 2012, Hajdúszoboszló

Kulisch Ágota, Benkő Ágota, Bergmann Annamária, Gyarmati Noémi, Horváth József, Kránicz Ágota, Mándó Zsuzsanna, Matán Ágnes, Németh András, Szakál Erika, Szántó Dóra, Szekeres László, Bender Tamás. Evaluation of the effect of Hévíz thermal water in patients with, osteoarthritis of the knee (a randomized controlled single-blind follow-up study). (poster presentation) Controversies in Rheumatology and Autoimmunity, 2013, Budapest

Kulisch Ágota, Benkő Ágota, Bergmann Annamária, Gyarmati Noémi, Horváth József, Kránicz Ágota, Mándó Zsuzsanna, Matán Ágnes, Németh András, Szakál Erika, Szántó Dóra, Szekeres László, Bender Tamás. A Hévízi-tó termál-ásványvízének vizsgálata primér térdarthrosisban szenvedő betegekre.

"Az egészségturizmus orvosi és turisztikai szemmel". 2013, Hévíz

Kulisch Ágota, Benkő Ágota, Bergmann Annamária, Gyarmati Noémi, Horváth József, Kránicz Ágota, Mándó Zsuzsanna, Matán Ágnes, Németh András, Szakál Erika, Szántó Dóra, Szekeres László, Bender Tamás. A Hévízi-tó termál-ásványvízének vizsgálata primér térdarthrosisban szenvedő betegekre (randomizált, kontrollált, egyszeresen vak, utánkövetéses vizsgálat). Orvosi Rehabilitáció és Fizikális Medicina Magyarországi Társasága XXXII. Vándorgyülése 2013, Miskolc 


\section{TABLE OF CONTENTS}

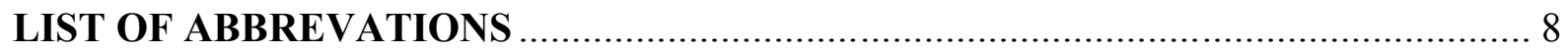

\section{LITERARY OVERVIEW}

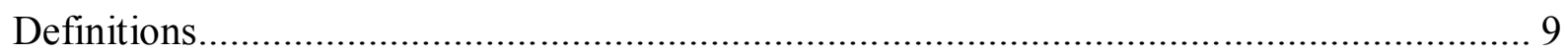

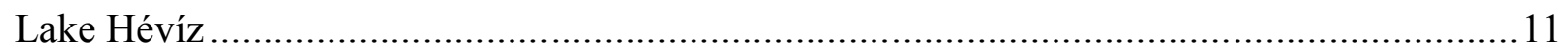

Assumed mechanism of action of hydro- and balneotherapy ........................................ 12

The definition, epidemiology, clinical presentation and recommended treatment of chronic

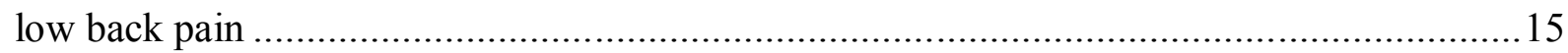

The definition, epidemiology, clinical presentation and recommended treatment of

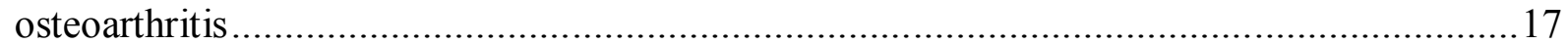

Evidences supporting the efficacy of balneotherapy in low back pain and osteoarthritis........19

Assessment of the effects of balneotherapy and the tools of health assessment.....................22

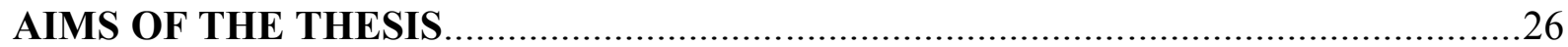

I. EFFECT OF THERMAL WATER AND ADJUNCTIVE ELECTROTHERAPY ON

CHRONIC LOW BACK PAIN: A DOUBLE-BLIND, RANDOMIZED, FOLLOW-UP STUDY

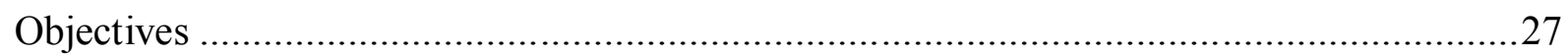

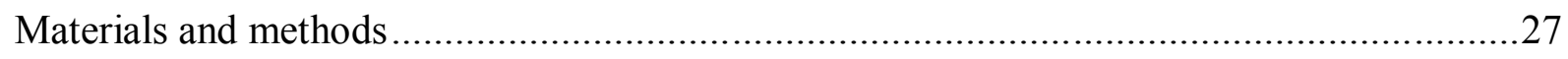

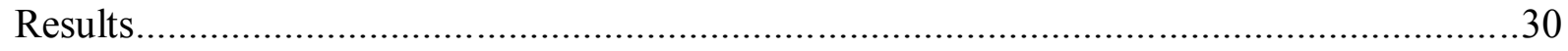

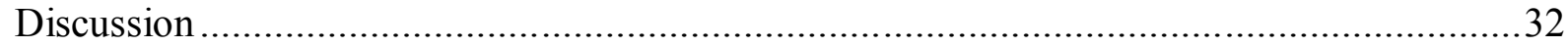

\section{EVALUATION OF THE EFFECT OF BALNEOTHERAPY IN PATIENTS WITH OSTEOARTHRITIS OF THE HANDS, A SINGLE-BLIND, RANDOMIZED, CONTROLLED FOLLOW-UP STUDY}

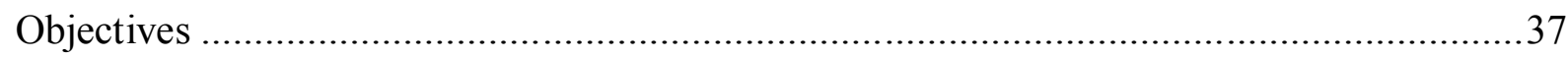

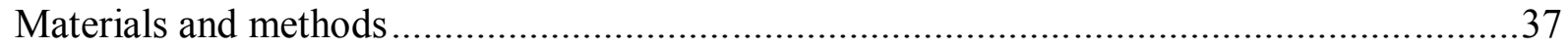

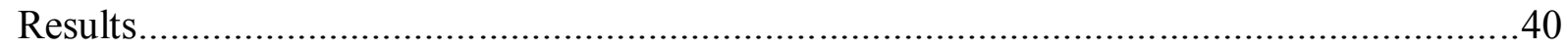

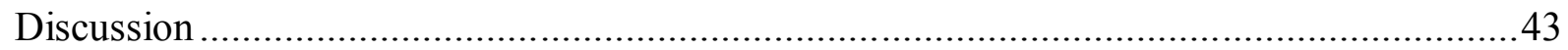


III. EVALUATION OF THE EFFECT OF LAKE HÉVÍZ THERMAL MINERAL WATER IN PATIENTS WITH OSTEOARTHRITIS OF THE KNEE, A SINGLEBLIND, RANDOMIZED, CONTROLLED FOLLOW-UP STUDY

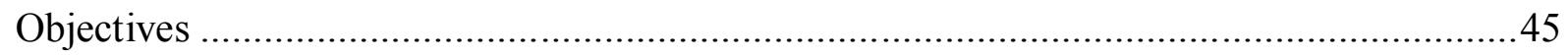

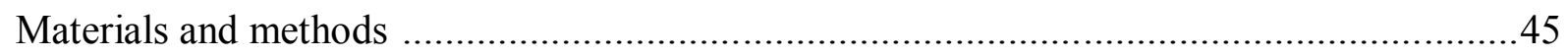

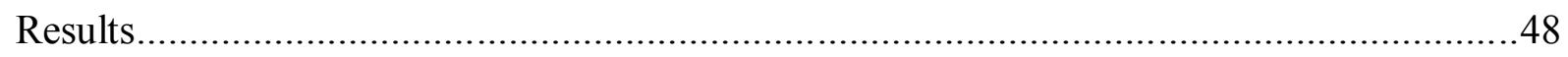

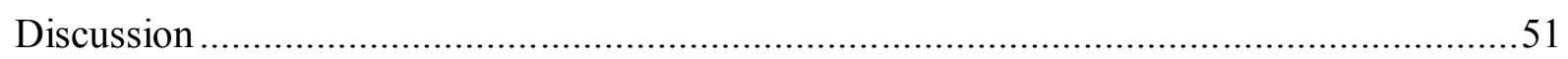

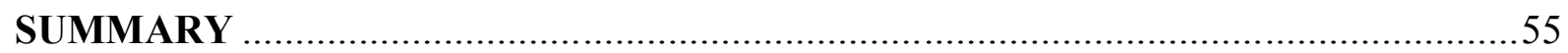

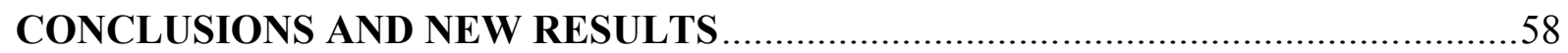

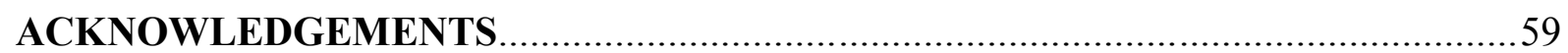

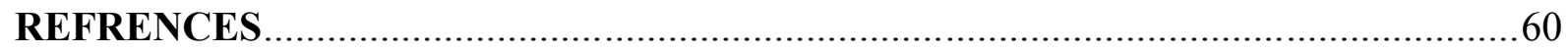

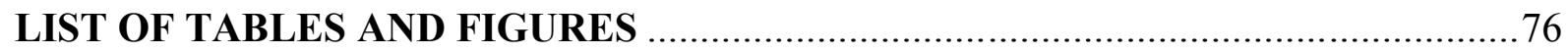

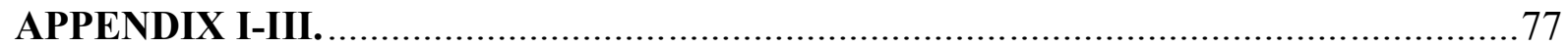




\section{LIST OF ABBREVATIONS}

ACR

CI

EQ-5D

EQ VAS

EULAR

IL

ITT

HAQ

LBP

MCII

MCS

MDC

MPCI

NS

NSAIDs

$\mathrm{OA}$

OARSI

ODI

$\mathrm{p}$

PCS

PP

PRO

$\mathrm{RCT}$

SD

SF-36

TNF- $\alpha$

TGF- $\beta 1$

TENS

VAS

WOMAC
American College of Rheumatology

Confidence interval

EuroQoL five dimensions questionnaire

EuroQoL visual analogue scale

European League Against Rheumatism

Interleukin

Intention-to-treat

Health Assessment Questionnaire

Low back pain

Minimal clinically important improvement

SF-36 Mental Component Summary

Minimal detectable change

Minimum perceptible clinical improvement

Non significant

Non-steroidal anti-inflammatory drugs

Osteoarthritis

Osteoarthritis Research Society International

Oswestry Disability Index

Value probability

SF-36 Physical Component Summary

Per protocol

Patient reported outcome

Randomized controlled trial

Standard deviation

Short Form (36) Health Survey quality of life questionnaires

Tumor necrosis factor alpha

Transforming growth factor beta 1

Transcutaneous electrical nerve stimulation

Visual analogue scale

Western Ontario and McMaster Universities Osteoarthritis 


\section{LITERARY OVERVIEW}

\section{Definitions}

Hungary is rich in thermal mineral waters due to its favourable hydrogeological endowments. Moving towards the centre of the Earth temperature rises. Geothermic gradient gives the distance in meters needed to get a temperature increase of $1{ }^{\circ} \mathrm{C}$. The temperature increase varies between $5-70^{\circ} \mathrm{C}$ per kilometer. In Hungary the average value of geothermal gradient is between $5-7^{\circ} \mathrm{C} / 100 \mathrm{~m}$, which is about 1.5 times higher than the world average. The reason for this is that the earth crust in the Pannon basin is thinner than the world average, and the basin is filled with sediments of good insulation potential. Regarding their chemical composition, mineral waters show great variation. The composition is determined primarily by the geological environment. Mineral waters can be extracted from the subterranean waters by natural processes, by springs, or by artificially drilled wells. Due to the geological structure and the geographical terrains in Hungary relatively few natural springs break up to the surface. In Hungary, there are two major hot spring reservoirs. One is under the great Plain, Small Plain and Drava riverside areas, containing the sodium-hydrogen-carbonate remains of the Pannon Sea, and in the deeper layers, sodium-chloride. The other is under the Transdanubia Hills containing calcium-magnesium-hydrogen-carbonated mineral water. The hot spring reservoirs are accessed by drilled wells to extract mineral water $[1,2]$.

Mineral waters may be classified by several aspects. The most accepted way of classification is grouping by chemical composition. Considering their composition, the mineral waters are classified as: salty (rich in calcium-chloride, magnesium-chloride), carbonated (sour waters), alkaline or calcined lime (sodium-hydrogen-carbonated, magnesium- hydrogen-carbonated), rich in iron, in iodine, in bromide, in sulfate, in sulfide, and radioactive waters. The role and impact mechanism of the organic content in mineral waters is not fully understood. The survey of organic content in mineral waters has been started [3].

In Hungary, the definition of natural healing factor as well as the accreditation and use of mineral waters, medical waters and thermal mud are regulated by national law. The water can be recognized as mineral water if it contains dissolved solid minerals of at least $1000 \mathrm{mg}$ per liter, or a specified quantity of minerals of specific impact, and it should not contain any materials harmful to human health, and the dissolved mineral content and chemical character 
should be stable. Medicinal water is a natural mineral water with healing properties proven by medical research [3].

In countries having no thermal water the medical use of tap water is widespread, and it is called hydrotherapy [4].

Balneotherapy a medical specialty using the beneficial effects of naturally found mineral waters, gases, and peloids. The most important modalities of use are bathing, drinking and inhalation. Bathing is immersion of the body or of body parts into water, peloid or gas. Drinking is a treatment method using ingestion of mineral waters. Inhalation is the application of aerosols from mineral waters and/or natural gases via the respiratory tract $[5,6]$.

The term balneotherapy comes from the Latin balneum (bath). It is called crenotherapy in France and Southern Europe. The term „spa therapy” is generally used in the English speaking world. The Vallonic word „espa” means „spring”, and this word is the origin of the name of the Belgian town Spa, where a healing thermal spring was discovered in the 14th century [7]. Spa therapy is complex patients receive treatment not only with thermal mineral water but also other modalities, such as massage, electrotherapy, and exercise [8].

Balneology is often not recognised as independent medical specialty at a global international level, because of the lack of scientific evidence, and the fact that balneotherapy is not available in all countries. A paper published in 2010 suggested the introduction of a new terminology, and medical field. This medical area can be defined as "medicine in health resorts" or "health resort medicine". "Health resort medicine includes all medical activities originated and derived in health resorts based on scientific evidence aiming at health promotion, prevention, therapy, and rehabilitation [5]".

In Hungary, the various balneotherapeutic options are widely available. In general, one therapeutic cycle consists of 15 to 20 sessions lasting at least 20 to 40 minutes each for a beneficial therapeutic effect [9]. Balneotherapy is usually part of a complex physiotherapeutic treatment. Balneotherapeutic procedures are mainly performed in musculoskeletal diseases [10] but their use have also been reported in various other indications such as in the treatment or rehabilitation of dermatological (psoriasis, atopic dermatitis) [11,12,13], gynaecological [14], chronic venous insufficiency [15,16], chronic occlusive arterial disease [17], or psychiatric conditions (generalized anxiety disorder) [18] as well as in the rehabilitation of oncology patients [19]. 


\section{Lake Hévíz}

Lake Hévíz deserves a special place within balneology/balneotherapy. The history of the lake goes back to the beginnings of the geological Middle Ages. Hévíz is the very last spring on the South-west of the karst waters stretching along the dolomites and karsts of the upper triassis of the Transdanubian mountains. We have several evidences to prove that the thermal water didn't spring on the recent water level but much higher than that. It started about 20-22 thousand years ago at the same place as it is today probably at the same time as Lake Balaton was forming. The rising water first was flowing into Lake Balaton. As an effect of climate changing the water level of Balaton was lowering. In the former basin of the lake peat was created from the plants living there before. As a result of this procedure the bottom of the lake, as well as the swamp around it consists of thick peat. Lake Hévíz is a biologically active, natural thermal lake located in West Hungary. It is Europe's largest warm water lake; only one natural formation similar to it exists in Rotorua, New Zealand. The spring of the lake, which has a water surface area of $45.000 \mathrm{~m}^{2}$, is rich in minerals and is located $38 \mathrm{~m}$ deep at the bottom of a vertical sandstone wall. The spring cave of the lake is divided into two halves by a mud layer. Several springs flow into the cave: one with cold karst water on the east side and one with thermal water on the west side. The spring feeding the lake keeps the water of the lake in a constant motion: the emerging water drifts towards the shores of the lake with slow circulation. The discharge of the lake is $410 \mathrm{~L} / \mathrm{sec}$ and with this the total water volume of the lake is replaced in about every three and a half days. The water of the lake is lead to river Zala by two canals and from there to Lake Balaton. During summer, water temperature reaches $37-38^{\circ} \mathrm{C}$ and it does not drop below $22-23^{\circ} \mathrm{C}$ even in winter. Resulting from the eventful earth history and geological characteristics, the lake forms a hydrogeological unit together with the surrounding moorland and marshland, which has a unique, special fauna characteristic for a hot spring [20]. The bed of the lake is covered with a 6 to $8 \mathrm{~m}$ thick mud layer. The microorganisms and their metabolites found in the water and in the mud contribute to the biological effects of the lake [21]. Károly Moll was the first in the world who applied the underwater traction in the form of weight-bath [22]. The therapy was developed at Lake Hévíz. Based on the lake and its special climate, Hévíz became a health resort with preventive, curative, and rehabilitative functions in the last centuries with adequate health care system and infrastructure. 


\section{Assumed mechanism of action of hydro- and balneotherapy}

The effects of balneotherapy are partly attributable to the aquatic environment and its basic physical characteristics as well as the effects of substances dissolved in the water $[23,24]$. Physiological changes evoked by the physical characteristics of water are well known. However, the role of dissolved minerals and organic substances in the mechanism of action of balneotherapy is not yet completely understood [25]. We call immersion when the body is dipped into water up to substernal height in a vertical position. The efficacy of hydrotherapy is explained by the water environment, the basic physical attributes of water i.e. its density, specific weight, hydrostatic pressure, buoyant force, viscosity and temperature [26]. On immersion, superficial veins are compressed, venous return is enhanced and central venous pressure, cardiac volume, stroke volume, and cardiac output are also increased [27]. At the same time, peripheral vascular resistance decreases. The redistribution of this higher cardiac output leads to an increased skin and muscle perfusion. The extent of cardiac output increase depends on age, sex, and water temperature [28]. Due to hydrostatic pressure, the circumference of body parts is reduced. On immersion to neck level, thorax is also under pressure. Moreover, enhanced thoracic blood return affects breathing as well. Vital capacity is reduced, inspiration is more difficult, and ventilation effort is increased. While breathing on immersion, primarily the muscles of inspiration exhibit an increased action [29]. Increased diuresis with a pronounced natriuresis and a less pronounced kaliuresis are seen. Vasopressine levels and plasma renin activity fall while atrial natriuretic peptide levels rise [30,31,32]. The initial haemodilution gradually normalizes [33].

On immersion, water is displaced by the body, generating upward buoyant force and gradually relieving submerging joints [26]. While moving in the water, internal friction is developed which depends on the viscosity of the fluid. As a result, certain movements are easier while others e.g. walking is more difficult to carry out. [34]. A man of $0.97 \mathrm{~kg} / \mathrm{m}^{3}$ density reaches a static equilibrium, or neutral buoyancy if $97 \%$ of his body is submerged into water [26]. Kjellgren et al investigated the floating form of the restricted environmental stimulation technique on patients suffering from chronic pain in the neck and back area. The flotation restricted environmental stimulation technique induced a significant reduction of pain intensity, anxiety and depression, significantly shorter latency to fall a sleep at night, and a significant decrease of noradrenaline metabolite values in the blood [35]. 
Water is an excellent therapeutic medium due to the combination of its high thermal capacity and high thermal conductance [36]. The analgesic effect of warm water is also explained by the gate control theory. Skin thermoreceptors and mechanoreceptors stimulated by the temperature and the hydrostatic pressure of water activate inhibitory interneurons acting on ascending nociceptive neurons, which, in turn, leads to the blockage of pain signal conductance [37]. Thermal effect induces changes in the neuroendocrine regulation. Heat as stress factor stimulates the secretion of adrenocorticotropic hormone, cortisol, prolactin, and growth hormone [38]. The increase of beta-endorphin levels was observed after bathing in hyperthermic mineral water or mud treatment. Elevated beta-endorphin level is thought to play a role in the development of tolerance to the substantial heat exposure associated with bathing. Repetitive elevation of beta-endorphin levels may contribute also to the mitigation of joint and muscle pain [39]. Water temperature has a delicate impact on the peripheral nervous system and the balance of sympathetic and parasympathetic effects. Becker et al examined biophysiologic effects of different temperatures water immersion to the autonomic nervous system. When compared with cool and neutral immersion, warm water immersion still produced a rise in sympathetic power with a small drop in sympathovagal balance from baseline. A rise in sympathovagal balance is associated with stress reduction, positive emotions. Such a physiologic change causes a decrease in cardiac irritability, a reduction in blood pressure, and a decrease in anxiety [40]. Thermal stimulation increases the extensibility of collagen-rich tissues, such as tendons, fasciae and articular capsules, which may improve the range of motion of joints [41]. By reducing muscle tone [35] and joint circumference [42] it contributes to the relief of musculoskeletal pain.

There is some evidence for the skin absorption of inorganic elements and organic substances from mineral waters. In a trial involved patients with psoriatic arthritis the authors detected a relevant increase in serum concentrations of bromine, rubidium, calcium, and zinc after bathing in the Dead Sea [43]. Hildebrandt and Gutenbrunner described relevant penetrations of sulphide through the skin by sulphide baths [44]. Nagy et al detected, that radon was capable of entering the human body through the skin during the bath therapy, and then was leaving it in a measurable quantity with the air exhaled. They demonstrated that the radon bath treatment may have an influence on endocrine organs. [45]. Experimental studies in animal models corroborate the evidence of beneficial effects of sulphurous balneotherapy 
on inflammatory diseases. Pozsgai et al have recently demonstrated an anti-inflammatory effect of sulphurous mineral water in dextran sulfate sodium evoked colitis in mice. Oral administration of Harkány thermal spring water significantly attenuated general signs of colitis [46]. In a study published in 2013 the effect of sulphurous medicinal water in a murine dermatitis model and on psoriatic patients was observed. The results provided evidence that somatostatin released by hydrogen sulfide plays role in the mechanism of action of sulphurous medicinal water [47]. The thermal stress has an immunosuppressive effect. In an in vitro study Markovic et al perceived that hyperthermia were able to suppress a series of pro-inflammatory genes (IL-1 $\alpha$, IL-1 $\beta$, TNF- $\alpha$, IL-8, monocyte chemoattractant peptide- 1 and cyclooxygenase-2) expression [48]. In ankylosing spondylitis patients, mild whole body hyperthermia caused a significant reduction of systemic levels of TNF- $\alpha$, IL-1 $\beta$, and IL-6 [49]. In addition to heat effect, immunosuppression might be mediated by chemical elements as well. In an in vivo study, a significant increase in TGF- $\beta 1$ was found in ankylosing spondylitis patients after spa (radon) therapy [50].

The decrease of pro-inflammatory prostaglandin E2 levels was seen after balneotherapy in patients suffering from fibromyalgia [51]. Balneotherapy induced a change in the concentration of pro-inflammatory markers playing an important role in osteoarthritis development as well as in the activity of cartilage-degrading proteases. In vitro studies demonstrated that sulfurous mineral water decreases IL-1 $\beta$ induced activation of fibroblastlike synoviocytes from patients with osteoarthritis [52]. Belometti et al found significant decrease of matrix metalloproteinase-3 levels after mud therapy [53]. Adipocytokines, including adiponectin, resistin may play an important role in the pathophysiology of osteoarthritis. Fioravanti et al measured the circulating levels of adiponectin, resistin after mud and balneotherapy in patients with knee osteoarthritis. A significant reduction of serum resistin and adiponectin was shown in knee patients after mud and balneotherapy [54].

The sulphur baths have effects on biochemical parameters. Ekmekcioglu et al demonstrated that sulphur baths can reduce the antioxidative defense system in the blood and moderately improve the lipid status [55]. Leibetseder et al showed that sulphur baths positively influence plasma homocysteine level [56]. Bender et al reported that balneotherapy has an influence on the antioxidant system, reducing the activity of catalase, superoxidedismutase, malondialdehyde, and glutathione-peroxidase [57]. 


\section{The definition, epidemiology, clinical presentation and recommended treatment of chronic low back pain}

Low back pain (LBP) is a major public health concern in many countries. LBP is the fifth most common reason for a patient to visit a physician's office in the United States of America [58]. The lifetime prevalence of LBP is up to $84 \%$. Peak prevalence occurs between ages 35 and 55 years [59]. LBP may prevent patients from returning to work and impair individuals to engage in activities required for daily living.

LBP is a multifactorial disorder with many possible etiologies, risk factors, and comorbidities. LBP designates pain or muscular tension between the margins of costae and the inferior gluteal folds that may be present with or without pain radiating to the leg. It is classified as specific LBP if it is caused by non mechanical spinal disorders/organic diseases such as cauda equina syndrome, spinal fracture, cancer, infection, spondyloarthritis, gastrointestinal or genitourinary diseases known as „red flags”. Undertake diagnostic triage consisting of appropriate history taking and physical examination at the first assessment to exclude serious spinal pathology and nerve root pain. If serious spinal pathology and nerve root pain are excluded, manage the low back pain as non-specific [59]. The majority of patients seeking care for LBP do not have a specific pathology or disease responsible for their symptoms, $85 \%$ to $95 \%$ of patients with low back pain do not have red flags [58]. Pathophysiologically, LBP may be caused by lumbar intervertebral discs, facet joints, sacroiliac joints, ligaments, fascia, muscles or nerve root dura which are capable of transmitting pain in the lumbar spine. Several concerns are related to the probability of a patient with chronic low back pain returning to work. Yellow flags were designed to identify patients with psychiatric disorders, emotional problems, or socioeconomic issues who could develop chronic pain and long-term disability. The assessment of prognostic factors in patients with chronic low back pain is recommended [59]. Back pain is usually defined as acute if it lasts less than six weeks; subacute if between six weeks and three months; and chronic when it lasts more than three months. Although $60 \%$ of people who have LBP recover in a few weeks and often with minimal intervention, for the other $40 \%$, recovery is slow and the risk of developing long-term symptoms, or chronic LBP, is high. The risk factors for a new episode of back pain are: a previous history of back pain, heavy physical work, frequent bending, twisting, lifting, pulling and pushing, repetitive work, static postures and vibrations 
$[60,61]$. Diagnostic imaging tests are not routinely indicated for non-specific low back pain. They serve two purposes: to evaluate patients with red flags or radicular pain, and to plan surgical techniques in those for whom surgery is being considered [59].

According to the Joint Clinical Practice Guideline from the American College of Physicians and the American Pain Society for Diagnosis and Treatment of Low Back Pain: clinicians should provide patients with evidence-based information on low back pain with regard to their expected course, advise patients to remain active, and provide information about effective self-care options. Furthermore clinicians should assess severity of baseline pain and functional deficits, potential benefits, risks, and relative lack of long-term efficacy and safety data before initiating therapy [62].

According to the Physical and Rehabilitation Medicine Section and Board of the European Union of Medical Specialists recommendation for the management of chronic LBP articles published in 2013, for pharmacological treatment paracetamol, nonsteroidal antiinflammatory drugs, tramadol and opioids, tricyclic antidepressants, duloxetin, for nonpharmacological modalities, education, back schools, exercise, massage, spinal manipulation, cognitive-behavioral therapy, multidisciplinary biopsychosocial rehabilitation were recommended. Management of LBP is strongly recommended by interdisciplinary rehabilitation team [63].

In an article published in 2011, the implications of evidence based practice guidelines recommendations for physical therapy practice for management of low back pain were reviewed. Sixteen guidelines were evaluated. The number of guidelines addressing chronic LBP (nine out of sixteen) was a little over half of that for acute LBP. The intervention choices for non-specific LBP were similar in the majority of the guidelines for acute (education, exercises, and spine manipulation), subacute (same as acute plus back school, behavioral counseling, or multidisciplinary rehabilitation), and chronic LBP (education and exercise plus back school, behavioral counseling, or multidisciplinary rehabilitation). Patients without red flags could be safely managed without specialist referral [64].

Balneotherapeutic procedures are often used by physicians and preferred by patients for the treatment of chronic low back pain. Because of the limited scientific evidence the balneotherapy are not included in the treatment guidelines for LBP. 


\section{The definition, epidemiology, clinical presentation and recommended treatment of osteoarthritis}

Osteoarthritis (OA) is thought to be the most prevalent chronic musculoskeletal disease. It usually results in pain and deformity, leading to chronic disability [65]. Limited movement ability of the joints, significant pain, and decreased muscle strength may develop, which may interfere with daily activities and overall quality of life. Worldwide estimates are that $9.6 \%$ of men and $18.0 \%$ of women aged $\geq 60$ years have symptomatic OA. OA was estimated to be the eighth leading non-fatal burden of disease in the world in 1990, accounting for $2.8 \%$ of total years of living with disability [66]. The incidence of osteoarthritis is rising because of the ageing population and the epidemic of obesity.

The prevalence of OA depends on the precise definition used. In a paper published in 2011, OA prevalence was studied in meta-analysis by sex and joint site (only data for knee, hip, and hand joints were evaluated) the highest OA prevalence estimates were found in hand joints and the hip is the joint with the lowest prevalence. OA of the knee tends to be more prevalent in women than in men but no gender differences were found in hip and hand OA. Higher OA prevalence was found in older populations. The analysis showed a higher prevalence when radiographic definition was used in all age groups and for both genders [67]. In the European Project on Osteoarthritis study, prevalence of knee OA was the highest, followed by hand OA, and hip OA, for both self-reported and clinical OA. Cross-national differences are observed in prevalence rates of both self-reported and clinical OA [68].

OA is characterized by focal areas of loss of articular cartilage within synovial joints, which are associated with hypertrophy of bone, osteophytes and subchondral bone sclerosis, and thickening of the capsule. Pathologic abnormalities are also present in periarticular muscle, ligaments, synovium, and in the neurosensory system. OA is a complex active degradative and repair process of cartilage and subchondral bone with a synovial inflammation. Risk factors of OA are obesity, female sex, ageing, oestrogen deficiency, family history, active subarticular bone remodeling, joint laxity, sport or occupational joint overload, prior injury with damaged ligaments and menisectomy, misalignment. Clinically, the condition is characterized by joint pain, tenderness, limitation of movement, crepitus, occasional effusion, and variable degrees of local inflammation. OA is classified into two groups according to the etiology of the disease: primary and secondary. In hand osteoarthritis, 
the most affected joints are the distal and proximal interphalangeal joints of fingers II to $\mathrm{V}$ and the carpometacarpal joint of finger I [69]. The extent of functional damage of the hand may be similar to that of in rheumatoid arthritis [70]. The American College of Rheumatology (ACR) has proposed a set of criteria for OA depending on each joint $[71,72]$.

Management requires early diagnosis and awareness of the risk factors that can affect the prognosis. In recent years a number of international evidence based guidelines developed for the management of OA. The guidelines included evidence and recommendations for a number of interventions including: pharmacological, non-pharmacological, surgical therapies, physical management and lifestyle changes for the management of OA. The therapeutic recommendations for OA emphasize the importance of reducing joint pain and stiffness, preserving joint mobility, and improving physical disability and quality of life $[73,74,75]$.

In 2012 the ACR has produced recommendations for the use of non-pharmacologic and pharmacologic therapies in OA of the Hand, Hip, and Knee. Both "strong" and "conditional" recommendations were made for OA management. Modalities conditionally recommended for the management of hand $\mathrm{OA}$ include instruction in joint protection techniques, provision of assistive devices, use of thermal modalities and trapeziometacarpal joint splints, and use of oral and topical nonsteroidal anti-inflammatory drugs (NSAIDs), tramadol, and topical capsaicin. Non-pharmacologic modalities strongly recommended for the management of knee OA were aerobic, aquatic, and/or resistance exercises as well as weight loss for overweight patients. Non-pharmacologic modalities conditionally recommended for knee OA included medial wedge insoles for valgus knee OA, subtalar strapped lateral insoles for varus knee OA, medially directed patellar taping, manual therapy, walking aids, thermal agents, tai chi, self-management programs, and psychosocial interventions. Pharmacologic modalities conditionally recommended for management of patients with knee OA included acetaminophen, oral and topical NSAIDs, tramadol, and intraarticular corticosteroid injections; intraarticular hyaluronate injections, duloxetine, and opioids. Recommendations for hip OA were similar to those for the management of knee OA [76].

Joint replacement is an effective intervention to alleviate pain and improve quality of life for those with advanced OA. However, despite a growing number of joint replacements undertaken each year many people are still placed on a waiting list often for a considerable time. In order to reduce the burden of OA, safe and effective health services, involving a 
range of non-surgical treatments options are required. These therapies must be effective with respect to intervention and cost as well as meet the affected person's needs. Due to adverse side effects, patients and health care providers may pursue physical management options rather than surgery, pharmacology, or injection based therapy. In the systematic review of seventeen guidelines for the physical management of OA forty therapeutic interventions were identified across the guidelines. Strongly recommended interventions included: exercise (combined exercise or unspecified type, aerobic, strengthening, aquatic/hydrotherapy, land based, yoga), transcutaneous electrical nerve stimulation, equipment (knee bracing, appropriate footwear, wedged insoles), education (pain management program, individual education, group education, pre-operative education, collective information), manual therapy (manual therapy with supervised exercise, manipulation and stretching), diet and weight loss, combinations of diet, physical activity, and social cognitive theory, self-management and psychosocial based therapy, balneotherapy (however only two guidelines provided recommendations for balneotherapy) [77].

In the recently published OARSI (Osteoarthritis Research Society International) Guidelines for Non-Surgical Management of Knee Osteoarthritis, balneotherapy was considered as an appropriate treatment for specific clinical subphenotypes with multiple joint osteoarthritis and comorbidities, based on systematic review and metaanalysis of randomized controlled trials [78].

\section{Evidences supporting the efficacy of balneotherapy in low back pain and osteoarthritis}

Evidence-based practice is the integration of clinical expertise, patient values, and the best research evidence into the decision making process for patient care. The best research evidence is usually found in clinically relevant research that has been conducted using sound methodology. There is an accepted hierarchy with respect to research evidence for the efficacy of treatments, the highest level being meta-analysis of randomised controlled trials (RCTs) [79]. Assessing the effectiveness of non-pharmacological treatments presents specific methodological issues. In non-pharmacological treatments trials, it is often difficult to perform sham intervention, and blinding of participants is frequently impossible. Intervention with balneotherapy also has the same issues. The success of balneotherapy often depends on environmental and other specific factors such as chemical and thermal characteristics, type of 
bath, nature, and combined intervention [80]. Despite the difficulties of organizing trials in the past decades, several clinical studies have evaluated the efficacy of balneotherapy mainly in the treatment of musculoskeletal diseases. Unlike for drug trials, the lack of adequate funding of balneology research makes it difficult to enroll sufficient numbers of patients in such trials. The metaanalysis of completed trials in balneotherapy is challenged by the diversity of their methods, therapies, and outcome parameters.

The number of studies on the effects of thermal water in the treatment of chronic low back pain is relatively small. A meta-analysis published in 2006 assessed the evidence for or against the effectiveness of spa therapy and balneotherapy for treating low back pain. Five randomized clinical trials met all inclusion criteria. Three of them tested the effectiveness of spa- and two them tested effectiveness of balneotherapy. The data assessed on a $100 \mathrm{~mm}$ visual analogue scale (VAS), suggest significant beneficial effects compared with control groups for patients with chronic low back pain. Results for the Schober index, assessing lumbar flexibility, suggested no significant intergroup differences. The methodological quality was on average adequate, given that patient blinding was not possible. There was no mention of adverse events even though the data are scarce, there is some encouraging evidence suggesting that spa therapy and balneotherapy may be effective for treating patients with low back pain. The authors encouraged further systematic research. Future studies should be randomized, adequate sample sizes should be assessed, ideally administering similar regimens under similar conditions [81].

Following the metaanalysis by Pittler et al., several trials were conducted in low back pain including that one presented in this work. The results of these trials were analyzed in the review of Karagülle et al in 2014. This review contained total of eight RCTs and 649 patients. The authors used Jadad checklist for methodological quality evaluation of the trials. Only three trials were graded as good quality, one balneotherapy trial a score of 5 (our study), and two spa therapy trials with score of 3 . Two RCTs tested effectiveness of two different balneotherapy methods six RCTs examined diverse spa therapy programs for LBP. Across a range of outcome measurements assessed in these publications, significant differential beneficial effects (most pronounced in reducing pain and improving function) in favor of spa therapy and balneotherapy have been shown in short and long terms. The quality of the RCTs evaluating balneotherapy and spa therapy for the treatment of low back pain is generally low. 
They concluded that balneotherapy and spa therapy seem to be beneficial in patients with LBP and might be considered as a non-pharmacological therapeutic option, but evidence on effectiveness of balneotherapy and spa therapy as therapy options in the treatment of LBP is yet insufficient and not conclusive [82].

The efficacy of balneotherapy has been most clearly evidenced in gonarthrosis. The first randomized, double-blind, tap water-controlled study evaluating the efficacy of balneotherapy in patients with knee osteoarthritis was published by Hungarian authors, Szücs et al in 1989. Study participants received thermal mineral water or tap water treatment for 20 minutes a day on 18 occasions; a decrease in joint pain and tenderness was noted in the thermal mineral water-treated group [83].

In a multicenter, randomized, controlled trial involving 382 patients with knee osteoarthritis published by Forestier et al in 2010, the spa therapy group received massage, showers, mud therapy, performed daily standardized exercises, and continued usual medical treatments in addition to thermal mineral water bathing. The control group performed daily exercises and continued usual medical treatments. The study included a month 6 follow-up visit, when visual analog scale, Western Ontario and MC Master Universities Arthritis Index, and Short Form (36) self-report questionnaires were used. Combined therapy proved to be more effective even during the 6-month follow-up period [84].

A Cochrane review published by Verhagen et al in 2008 was based on the analysis of 7 randomized, controlled trials. Silver level evidence was found concerning balneotherapy in osteoarthritis. Because of the poor methodological quality and the absence of an adequate statistical analysis and data presentation, the scientific evidence is weak. The authors emphasize the need for further additional, confirmatory studies [85].

In a systematic review published in 2009, Falagas et al analyzed the results of randomized, controlled studies evaluating the efficacy of balneotherapy published between 1950 and 2006. Results of 29 RCTs regarding balneotherapy in various medical fields were analyzed. Twenty-two studies included patients with rheumatologic and musculoskeletal diseases. Eight of them were conducted in patients with osteoarthritis. Despite the heterogeneous study population of the evaluated RCTs, there seems to be a beneficial effect of balneotherapy in the majority of them. The authors suggested that balneotherapy is 
associated with clinical improvement mainly in rheumatic diseases such as osteoarthritis, fibromyalgia, ankylosing spondylitis, rheumatoid arthritis and in chronic low back pain [86].

A systematic review published by Harzy et al in 2009 evaluated the short- and longterm effects of balneotherapy in knee osteoarthritis by analyzing the results of RCTs. The results of 9 RCTs were evaluable, including data from 493 patients. All therapies used in these trials resulted in decrease of pain and improvement of function and the improvements were measurable even after 24 weeks. No serious adverse effects were observed. The authors of both reviews suggested that further RCTs should be conducted [87].

A systematic review and meta-analysis published by Bender $\mathrm{T}$ et al in 2013, analyzed the results of studies evaluating the effect of Hungarian thermal mineral waters published by Hungarian authors between 1989 and 2012 in the English literature. Out of the 122 studies, 18 were clinical studies, and 9 of these met the criteria for meta-analysis. Out of these 9 studies, 4 involved patients with chronic low back pain, 2 with knee and 2 with hand osteoarthritis, and 1 with chronic inflammatory pelvic disease. The primary endpoint of the meta-analysis was the measurement of the pain-reducing effect of balneotherapy. Regardless of the composition of the mineral water, balneotherapy significantly decreased joint pain at rest and on exertion in patients with chronic low back pain and knee and hand osteoarthritis [88].

\section{Assessment of the effects of balneotherapy and the tools of health assessment}

The assessment of a patient suffering from chronic musculoskeletal diseases should include evaluations of pain, function, and quality of life. Global pain or disability can also be evaluated using a visual analog scale (VAS). A patient reported outcome (PRO) is a method or questionnaire used in a clinical trial or a clinical setting where the responses are collected directly from the patient. The PROs provide intrinsic knowledge about a patient's health, functional status, symptoms, treatment preferences, satisfaction, and quality of life.

When measuring treatment effect in osteoarthritis/chronic low back pain with multi-item outcome instruments, it is necessary, both for clinical decision-making and research purposes, to understand the clinical importance of the outcome scores. The minimal clinically important improvement (MCII), defined as the smallest change in measurement that signifies an important improvement in a patient's symptom. Tubach et al in a prospective cohort study aimed at estimating the MCII from the patient's perspective for three main patient reported outcomes used 
in OA trials: pain, patient's global assessment of disease activity (measured on visual analogue scales 0-100 $\mathrm{mm}$ ), and functional impairment (measured on the Western Ontario McMaster Universities Osteoarthritis Index function subscale 0-100). For knee OA MCII for absolute (and relative) changes were, respectively, $-19.9 \mathrm{~mm}$ for pain; $-18.3 \mathrm{~mm}$ for patient's global assessment; -9.1 for WOMAC function subscale score [89].

Hagg $\mathrm{O}$ et al aimed to estimate the minimal clinically important difference of three multiitem outcome instruments (the Oswestry Disability Index, the General Function Score and the Zung Depression Scale) and of the VAS of back pain. The study population consisted of 289 patients treated surgically or non-surgically in a randomised controlled trial. The minimal clinically important difference of VAS back pain was 18-19 units. The minimal clinically important difference was 10 units for Oswetry Disability index score [90].

The Western Ontario and MC Master Universities Arthritis Index (WOMAC) is often used, standardized questionnaires to appreciate condition of patient with OA of the knee and the hip, including pain, stiffness, and physical functioning of the joints. The WOMAC measures 5 items for pain, 2 for stiffness, and 17 for functional limitation. Physical functioning questions cover everyday activities. The WOMAC has been used in both observational/epidemiological studies and to examine changes following treatments including pharmacotherapy, arthroplasty, exercise, physical therapy, knee bracing, and acupuncture. Higher scores on the WOMAC indicate worse pain, stiffness, and functional limitations [91]. Study has shown that WOMAC and SF-36 subscales with similar constructs have moderate to high correlations [92]. The WOMAC has shown significant correlations with performance scores for walking, stair climbing, rising from a chair, and joint range of motion among older adults with knee and hip OA [93]. The WOMAC is validated in Hungarian [94].

The Health Assessment Questionnaire (HAQ) is based on five patient centered dimensions: disability, pain, medication effects, costs of care, and mortality. Typically, one of two HAQ versions is used: the Full HAQ, which assesses all five dimensions, and the Short or 2-page HAQ, which contains only the HAQ disability index (HAQ-DI) and the HAQ's patient global and pain visual analog scales (VAS) [95]. The HAQ-DI has also been administered in a variety of diseases and conditions, including osteoarthritis, juvenile rheumatoid arthritis, systemic lupus erythematosus, ankylosing spondylitis, fibromyalgia, psoriatic arthritis, and systemic sclerosis [96]. HAQ was compared with WOMAC and was found to be similarly and significantly 
correlated [97]. The HAQ-DI, assesses a patient's level of functional ability and includes questions of fine movements of the upper extremity, locomotor activities of the lower extremity, and activities that involve both upper and lower extremities. Standard scoring takes into account the use of aids and devices or assistance from another person. There are 20 items in eight categories that represent a comprehensive set of functional activities - dressing, rising, eating, walking, hygiene, reach, grip, and usual activities. For each item, there is a four-level response set that is scored from 0 to 3, with higher scores indicating more disability. To calculate the HAQ-DI, the highest subcategory score determines the value for each category. The category scores are then averaged into an overall HAQ-DI from zero to three. Scores of 0 to 1 generally represent mild to moderate difficulty, 1 to 2 represent moderate to severe disability, and 2 to 3 indicate severe to very severe disability [95]. The HAQ-DI is validated in Hungarian [98].

The Oswestry Disability Index (ODI) is an index originated from the Oswestry Low Back Pain Questionnaire to quantify disability for low back pain. The self-completed questionnaire includes ten topics related intensity of pain, lifting, ability to care for oneself, ability to walk, ability to sit, sexual function, ability to stand, social life, sleep quality, and ability to travel. Each topic category is followed by 6 statements describing different potential scenarios in the patient's life relating to the topic. Each question is scored on a scale of $0-5$ with the first statement being zero and indicating the least amount of disability and the last statement is scored 5 indicating most severe disability. The scores for all questions answered are summed then multiplied by two to obtain the index (range 0 to 100). 0 to 20: Minimal disability, 21-40: Moderate Disability, 41-60: Severe Disability, 61-80: Crippling back pain, 81-100: These patients are either bed-bound or have an exaggeration of their symptoms [99]. The ODI is validated in Hungarian [100].

The Short Form (36) (SF-36) is an all-purpose, short-form patient reported health survey with 36 questions. The SF-36 has proven useful in surveys of general and specific populations, comparing the relative burden of diseases, and in differentiating the health benefits produced by a wide range of different treatments. The SF-36 has undergone modifications. The Version 2.0 fivelevel response scales substantially improve the two SF-36 role functioning scales. The SF-36 is available in both standard (4-week) and acute (1-week) recall versions. The SF-36 consists of eight scaled scores, which are the weighted sums of the questions in their section. Each scale is directly transformed into a $0-100$ scale on the assumption that each question carries equal weight. 
The higher the score the less disability i.e., a score of zero is equivalent to maximum disability and a score of 100 is equivalent to no disability. The eight sections are: Vitality - V, Physical Functioning - PF, Role Physical - RF, Bodily Pain - BP, General Health - GH, Role Emotional RE, Social Functioning - SF, Mental Health - MH. Three scales (PF, RP, BP) correlate most highly with the physical component and contribute most to the scoring of the Physical Component Summary (PCS) measure. The mental component correlates most highly with the MH, RE, and SF scales, which also contribute most to the scoring of the Mental Component Summary (MCS) measure. Three of the scales (VT, GH, and SF) have noteworthy correlations with both components [101]. The SF-36 is validated in Hungarian [102].

The EuroQoL five dimensions questionnaire (EQ-5D-3L) "essentially consists of the EQ-5D descriptive system and the EQ visual analogue scale (EQ VAS). The EQ-5D-3L descriptive system contains the following 5 dimensions: mobility, self-care, usual activities, pain/discomfort and anxiety/depression. Each dimension has 3 levels: no problems, some problems, extreme problems. A unique health state is defined by combining 1 level from each of the 5 dimensions. A total of 243 possible health states are defined in this way. Each state is referred to in terms of a 5 digit code. EQ-5D health states, defined by the EQ-5D descriptive system, may be converted into a single summary index by applying a formula that essentially attaches values to each of the levels in each dimension. The EQ VAS records the respondent's self-rated health on a vertical, visual analogue scale where the endpoints are labelled "Best imaginable health state" and "Worst imaginable health state". The EQ-5D-3L (EQ-5D 3 level) self-complete paper version is currently translated in more than 170 language versions" [103]. 


\section{AIMS OF THE THESIS}

Metaanalyses and review studies on the efficacy of balneotherapy evaluated the analyzed randomized, controlled trials as of inappropriate methodology. Therefore, we aimed to design our studies with appropriate methodology, in accordance with the recommendations for study planning. These trials may provide data for a more precise evaluation of the role of balneotherapy in the management of each condition.

I. Our aim was to evaluate the effectiveness of thermal mineral water compared with tap water and supplementary electrotherapy in patients with chronic low back pain first in the English literature in a double-blind trial. As primary endpoint, we aimed to monitor changes in low back pain, movement functions, and quality of life of the enrolled patients. Secondary end-points were to record changes in the dose requirements of analgesics and explore the safety profile of treatment.

II. There have been several publications about the use of balneotherapy in knee osteoarthritis. The effect of balneotherapy on hand osteoarthritis has not yet been studied. Our aim was to evaluate the efficacy of thermal water, mineral water, and supplementary magnetotherapy in patients with hand osteoarthritis. The primary endpoint was the effect of balneotherapy on hand pain, hand functions, and quality of life. As secondary endpoint, we assessed whether there is any clinically significant, evaluable difference in the effect of waters of different temperature.

III. Studies involving patients with knee osteoarthritis and systematic reviews confirmed the analgesic and knee function improving effect of balneotherapy. However, in most of the studies, bath therapy was combined with other therapies. Furthermore, only a limited number of previous studies covered the assessment of quality of life. Therefore, the primary endpoint of the study was the evaluation and documenting of the pain-reducing effect of Lake Hévíz thermal mineral water on knee pain at rest or on exertion in patients with mild to moderate knee osteoarthritis as well as the assessment of the therapeutic effect compared to the control group treated with warmed tap water. The secondary endpoints included the evaluation of the effect of Lake Hévíz thermal mineral water on knee function and quality of life. 


\section{EFFECT OF THERMAL WATER AND ADJUNCTIVE ELECTROTHERAPY ON CHRONIC LOW BACK PAIN: A DOUBLE-BLIND, RANDOMIZED, FOLLOW-UP STUDY}

\section{OBJECTIVES}

The number of studies on the effects of thermal water in the treatment of chronic low back pain is relatively small. The first meta-analysis available in English [81] evaluated pooled data from only 5 studies [104,105,106,107,108]. The first single-blind study [109] was published concomitantly with the above meta-analysis. No double-blind studies have been reported so far. The aim of the current study was to evaluate the effectiveness of thermal mineral water compared with tap water in the treatment of patients with low back pain, with pain level, mobility and quality of life as primary end-points. Secondary end-points were to record changes in the dose requirements of analgesics and explore the safety profile of treatment.

\section{MATERIALS AND METHODS}

\section{Design}

In this randomized, controlled, double-blind, follow-up study, we evaluated the effects of thermal mineral water and adjunctive electrotherapy on chronic low back pain. This study was implemented in observance of the rules of good clinical practice. The study protocol was approved by the Regional Research Ethics Committee.

\section{Participants}

Male and female patients aged 25-70 years living in and around the town of Celldömölk who presented with chronic lumbar pain of more than 12 weeks' duration were included in the study. Subjects were recruited by 3 local general practitioners (GPs). The three GPs and the investigators cross-checked the inclusion and exclusion criteria among themselves before the launch of the study. The GPs invited patients with chronic lumbar pain to participate in the study. Enrolled patients completed the balneotherapy treatment as outpatients, with no change in their daily routine or work attendance. The GPs were on call to deal with potential adverse reactions or other treatment- related problems. All subjects were informed about the purpose, conditions and course of the study prior to inclusion. Patients were given written explanation of 
the treatment prior to giving their written informed consent. Patients with the following conditions were excluded from the study: acute pain; acute organic neurological deficit accompanying low back pain; confirmed osteoporosis, neoplastic or inflammatory lesion as the underlying cause of low back pain; decompensated cardiovascular disease; unstable hypertension, angina pectoris; uncontrolled endocrine disease (hyperthyroidism, hyperparathyroidism); other uncontrolled and unstable metabolic disorders (diabetes mellitus, hyperuricaemia, hyperlipoproteinaemia); acute febrile infections; cutaneous suppuration; pregnancy; decompensated psychosis/neurosis. Patients who had received any kind of physiotherapy during the 3-month period prior to the study were similarly excluded.

\section{Study procedures}

The study was conducted at the spa of Celldömölk in Hungary, which opened in 2005. Patients were randomized into either of the 2 treatment groups. One group was treated with thermal water, whereas the other group was treated with tap water. The water temperature was $34^{\circ} \mathrm{C}$ for both groups. Subjects underwent 20-min balneotherapy sessions daily for 3 weeks. Both treatment groups received additional electrotherapy under standardized conditions. Diadynamic current (long period current with waist electrodes of standard size, and discharge duration of $3 \mathrm{~min}$ ) was applied 3 times per week, before the balneotherapy sessions. The patients were monitored continuously during the treatment sessions. The study protocol required patients to attend at least $80 \%$ of treatments, i.e. a minimum of 17 balneotherapy sessions. Baseline and post-balneotherapy assessments were performed by either of 2 rheumatologists. The rheumatologists standardized the methodology of the measurements and tests by jointly examining nonparticipating patients prior to the study. The subjects were assessed 3 times: at baseline, after 3 weeks and after 15 weeks.

\section{Randomization and blinding}

Randomization was performed by an individual who was not involved in the implementation of the study. It was a simple randomization with a random-number table. Except for the bath attendants, neither the subjects, nor the investigators were aware of the randomly assigned treatment. The investigators examined the study subjects simultaneously, but in different offices. On the first occasion, patients were randomly assigned to an investigator. Subsequently, however, every investigator assessed the same subjects he/she had examined at 
the first visit. The professional performing the statistical analysis was aware of the randomization.

\section{Evaluations}

The properties of low back pain were appraised using 100 -mm visual analogue scales (VAS), as follows. VAS I: the severity of low back pain at rest, as rated by the patient. VAS II: the severity of low back pain upon exertion, as rated by the patient. VAS III: perceived status, as rated by the patient. VAS IV: the patient's progress, as rated by the investigator. The range of mobility of the lumbar spine was estimated by performing Schober's test and the Domján R and L tests (the right, left lateral flexion of the lumbar spine in $\mathrm{cm}$ ) [110]. The Oswestry Disability Index was used to assess the functions of the lumbar spine. The subjects' quality of life was evaluated with the SF-36 questionnaire.

\section{Thermal water composition}

The water source used was the well "Cell-4" at Vulcan Spa, Celldömölk, Hungary. This is a very mild mineral water rich in solutes (sodium hydrogen carbonate and chloride), also containing fluoride and a substantial amount of iodides (Table 1.). The appearance of the tap water was changed to resemble that of the thermal water; through the addition of extract of green walnut husks. The characteristic smell of the thermal water was simulated by using bathtubs located in the same hall as the treatments with thermal water were undertaken.

Table 1. Mineral composition of thermal water

\begin{tabular}{llll}
\hline $\begin{array}{l}\text { Total hardness of water } \\
\text { Total solute content }\end{array}$ & & $12 \mathrm{mg} / \mathrm{CaO} / 1$ & \\
\hline Cations & $\mathbf{m g} / \mathbf{l}$ & $3350 \mathrm{mg} / \mathbf{l}$ & \\
\hline Sodium & 9501 & Anions & $\mathbf{m g} / \mathbf{l}$ \\
Potassium & 5.9 & Chlorine & 530 \\
Calcium & 5.5 & Iodides & 0.66 \\
Magnesium & 1.7 & Hydrogen carbonate & 1600 \\
\hline \hline
\end{tabular}

\section{Statistical methods}

Data were entered into and analysed with MS Excel software. Statistical comparisons were made using single-sample (paired) and 2-sample $t$-tests. Intention-to-treat (ITT) analysis was performed. All patients were taken into account upon evaluation of the results. Retrospectively, the likelihood of absenteeism from study visits was not related to the absolute 
value of missing data and accordingly, these could be regarded as incidental deficiencies. Missing data of drop-outs were substituted with the last measured value in order to avoid overestimation of the therapeutic effect. A separate analysis (a per protocol (PP) analysis) was carried out for patients who completed the full treatment course in compliance with study requirements. This afforded approximate assessment of efficacy variables following intervention under optimal circumstances. The level of significance was set at $p<0.05$.

\section{RESULTS}

Recruitment of patients began in January 2007 and the study was launched at the end of February 2007. Of the 71 patients included in the study, 64 completed more than $80 \%$ of the therapy course. Demographic and baseline clinical characteristics of patients in the ITT population are shown in Table 2.

Table 2. Demographic data and other baseline clinical characteristics of the patients by treatment group

\begin{tabular}{lcc}
\hline & Thermal water group $(\mathbf{n}=\mathbf{3 6})$ & Control group $(\mathbf{n}=\mathbf{3 5})$ \\
\hline Postoperative condition & 6 & 7 \\
No. male/female & $23 / 13$ & $23 / 12$ \\
Age, years mean (SD) & $57.6(7.9)$ & $56.3(7.5)$ \\
\hline \hline
\end{tabular}

The 2 treatment groups were similar with regard to demographic data and baseline clinical characteristics. Seven patients discontinued the treatment period after 3 weeks ( 5 patients in the thermal group, and 2 patients in the tap water group). A further 13 patients ( 2 from the thermal water group and 11 from the control group) did not return for the 15-week control visit. The disposition of the patients is presented in Figure 1.

Figure 1. Disposition of the patients

\begin{tabular}{|c|c|}
\hline Patients randomly allocated to treatment $(n=71)$ & to treatment $(n=71)$ \\
\hline$\downarrow$ & 7 \\
\hline $\begin{array}{l}\text { - Allocated to intervention group }(n=36) \\
\text { - Received allocated intervention }(n=31) \\
\text { - Did not receive allocated intervention }(n=5) \\
\text { (3: lack of compliance; 1: febrile infection; } \\
\text { 1: cataract surgery) }\end{array}$ & $\begin{array}{l}\text { - Allocated to control group }(n=35) \\
\text { - Received allocated intervention }(n=33) \\
\text { - Did not receive allocated intervention }(n=2) \\
\text { (1: febrile infection; 1: gynaecological surgery) }\end{array}$ \\
\hline$\downarrow$ & $\nabla$ \\
\hline Lost to follow-up ( $n=2)$ (lack of compliance) & Lost to follow-up ( $n=11$ ) (lack of compliance) \\
\hline$\downarrow$ & $\downarrow$ \\
\hline $\begin{array}{l}\text { - Analysed intention to treat }(n=36) \\
\text { - Analysed per protocol }(n=29)\end{array}$ & $\begin{array}{l}\text { - Analysed intention to treat }(n=35) \\
\text { - Analysed per protocol }(n=22)\end{array}$ \\
\hline
\end{tabular}


ITT analysis at the end of 3 weeks treatment revealed a decrease in VAS scores for both groups. Within-group comparison to baseline showed significant improvement of pain at rest (VAS I $\mathrm{p}<0.01$ ), lumbar pain on exertion (VAS II $\mathrm{p}<0.01$ ), perceived status as rated by the subjects (VAS III $\mathrm{p}<0.01$ ), as well as the patient's general condition as rated by the investigator (VAS IV $\mathrm{p}<0.01$ ) for both treatment groups. The improvement remained significant for all 4 parameters after 15 weeks in the group treated with thermal water $(\mathrm{p}<0.01)$. In the control group only 2 parameters, VAS II and VAS IV scores remained significantly $(\mathrm{p}<0.05)$ improved after 15 weeks.

Between-group analysis gave the following results. Within the 3-week study interval patients receiving thermal water therapy showed a significant therapeutic response, with a decrease in VAS IV scores compared with the control group $(-14.8$ (95\% CI -18.9 to -10.7$)$ vs $-8.2(95 \% \mathrm{CI}-14.1$ to -2.4$) \mathrm{p}<0.05)$. After week 15 , the changes in VAS III scores between baseline and the end of the study were significantly greater in the thermal water group $(-17.6(95 \%$ $\mathrm{CI}-22.9$ to -12.4$)$ vs $-5.2(95 \% \mathrm{CI}-13.9$ to 3.4$) \mathrm{p}<0.05)$.

A similar trend was revealed by the results of the tests evaluating the range of motion of the lumbar spine (Schober's, Domján's R-L, Oswestry). While the improvement shown by these 4 tests was still statistically significant after 3 weeks in the thermal water group, only the Domján R and L tests remained significantly improved in the control group $(\mathrm{p}<0.05)$.

After week 15, however, only Domján L and Oswestry scores of the thermal water group were significantly superior compared with baseline values $(p<0.05)$. At the end of 3 weeks, there was no significant difference when comparing the test results between the thermal water and the control group. Significant improvement was seen after week 15 in the Schober's index in the thermal water group compared with the control group $(0.08$ (95\% CI -1.12 to 1.29) vs $-1.79(95 \% \mathrm{CI}-3.09$ to -0.48$) \mathrm{p}<0.05)$.

By the end of week 3 quality of life indicators, SF-36 items (PF: Physical Functioning, RP: Role Physical, BP: Bodily Pain, GH: General Health, V: Vitality, SF: Social Functioning, RE: Role Emotional, MH: Mental Health) improved significantly both in the thermal water and in the control group $(\mathrm{p}<0.01)$ compared with baseline. The improvement in quality of life compared with baseline remained significant for both groups after 15 weeks. Although the improvement after week 15 was still significant compared with baseline, as shown by the PF, RP, BP, GH, V, RE items in the thermal water group $(p<0.01)$ and by the RP, V, RE items in the control group $(p<0.05)$, the outcome status of the 2 groups was not statistically different. 
The 2 groups were also compared for patients who completed the full treatment course according to the study protocol. A total of 51 patients (29 in the thermal water and 22 in the control group) were analysed separately (PP analysis). The results were consistent with those of the ITT analysis, but between-group differences and the extent of the therapeutic response showed significantly greater improvement in the thermal water group. Means and 95\% CI are shown in Table III. After 3 weeks, significant between-group differences were seen in the changes of VAS IV scores, in Schober's and Oswestry, as well as in SF-36 BP ( $\mathrm{p}<0.05)$. After week 15, however, the thermal water group proved significantly superior to controls with regards to the changes in VAS I scores, Schober's, and Domján's L indices compared with their baseline values $(p<0.05)$. After week 15, none of the SF-36 parameters indicated a significant change in the control group. Comparison of the 2 groups showed that the improvement of PF after week 15 was significantly greater in the thermal water group than in controls $(\mathrm{p}<0.05)$.

No adverse reactions were observed during treatment sessions or during the whole study period. Potential changes in the efficacy of analgesic therapy could not be monitored, due to the small number of subjects who took analgesics regularly; statistical analysis of this parameter therefore proved unfeasible.

\section{DISCUSSION}

Overall, study parameters indicated a tendency for positive physiological changes in both groups. In the group treated with thermal water, improvement occurred earlier, lasted longer, and was statistically significant in more patients, both in within-group and in between-group comparisons. Compared with controls, however, the statistically significant difference (in VAS III, VAS IV scores and Schober's index) between the groups was smaller than the (more substantial) improvement expected on theoretical grounds. While the analgesic effect of thermal water is well known, the short-term relief seen among controls emphasizes the beneficial, relaxing effect of hydrotherapy with hot water [8]. In contrast to the ITT analysis, the PP analysis demonstrated the advantage of the thermal water group over controls, as reflected by the improvement in a greater number of study parameters (VAS IV, Schober's, Oswestry, SF-36 BP on week 3 and VAS I, Schober's, Domján L, SF-36 PF on week 15). Evidently, the statistical power of the PP analysis is weaker in a double-blind placebo-controlled trial; however, presenting the results of patients who have completed the study in compliance with the protocol was deemed 
important, to demonstrate the statistical significance of differences in addition to the statistical trend revealed. The first controlled, double-blind study of balneotherapy was reported in the literature by Hungarian authors in 1989 [83]. Since that time, an increasing number of papers have been published on the favorable effects of balneotherapy in a variety of musculoskeletal disorders including rheumatoid arthritis [111], ankylosing spondylitis [112], osteoarthritis [113,114] and fibromyalgia [115]. The majority of papers regard treatment with thermal water as an element of complex therapy, although there are also reports on monotherapy. Several papers have discussed the methods developed for measuring the efficacy of spa therapy [116,117]. In contrast to previous appraisals of spa therapy, our study compared thermal water with tap water, and not with pharmacotherapy of other treatment modalities. In our study, adjunctive electrotherapy did not exert any substantial analgesic effect. Only a few studies have investigated the effects of diadynamic current [118]. According to the tap water-controlled, single-blind study of Balogh et al, long-term relief of pain, muscle spasm and tenderness of paravertebral muscles, as well as the improvement of the range of motion of the lumbar spine was significant in the group treated with thermal water (containing sulphur) only [109].

In their study on outpatients undergoing therapy for low back pain, Konrad et al [107] reported the results of treatment with 3 different modalities (thermal water, underwater jet massage, weight bath) in comparison with untreated controls. All 3 groups on active treatment improved, and one year later their analgesic dose requirements were lower than that of controls.

Guillemin et al. compared the effects of 3-week balneotherapy (15-min underwater jet massage in $36^{\circ} \mathrm{C}$ water, followed by $3-$ min showering with water of $31-36^{\circ} \mathrm{C}$ temperature) with that of outpatient management, in patients with low back pain. Analgesic use (upon prescription by the family practitioner) was allowed in both groups, but other modalities of physiotherapy were not. Assessments were undertaken at baseline, on day 26 of treatment, and 9 months after the end of therapy. Compared with controls, the improvement of several parameters (VAS score, Schober's sign, lumbar spine mobility, reduction of analgesic requirements) was evident immediately after treatment, and (except for the Waddell disability score) proved lasting even 9 months later [104].

Another French study randomized 121 patients with low back pain into 2 groups treated with either balneotherapy (for $10 \mathrm{~min}$, followed by packing with $45^{\circ} \mathrm{C}$ mud for $20 \mathrm{~min}$., and then, high-pressure showering for $2.5 \mathrm{~min}$.) or with pharmacotherapy only. Study parameters 
(Schober's index, finger-floor distance, pain scale scores, Roland \& Morris Disability Questionnaire, analgesic requirements) were substantially improved immediately after treatment and 6 months later, thereby demonstrating the long-term effect of balneotherapy [105].

According to Constant et al [106], spa therapy enhanced the quality of life evaluated with the Duke Health Profile Questionnaire of 128 treated patients (compared with that of 96 controls) and improvement persisted 3 months later.

In 2006 we reported the results of our pilot study. This randomised, single-blind, controlled, follow up study included 42 patients with chronic low back randomly assigned into three groups. In group I subjects $(n=20)$ bathed in Lake Hévíz, and in group II $(n=11)$ patients were treated in a pool full of thermal-mineral water, the third group $(n=11)$ received hydrotherapy in a pool of tap water. Participants underwent 30 minutes therapy sessions, every 1-3 days, on 15 occasions. At the start and at the end of the treatment: all participants completed a quality of life and daily life functions questionnaire (SF-36), and short test for measuring depression (Beck Depression Inventory) and the Oswestry Disability Index questionnaire. The patients' pain was recorded by using visual analog scale score. 3 and 6 months after starting treatment the SF-36 questionnaires were repeated. Within-group comparison to baseline showed significant improvement of lumbar pain as rated by the subjects in all groups. Statistically significant improvement was observed in lumbar pain parameter after the treatment in the thermal-mineral water groups versus the group III. The responders' self-rated health measured on the Beck Depression Inventory and Oswestry Disability Index scale slightly improved, but the changes were not statistically significant in the three groups. Because of the small number of cases evaluation of the SF-36 data only in the group I (Lake Hévíz) were processed. After the treatment and during the 3 months follow-up period all SF-36 items improved significantly in the group I compared with baseline. During 6 months follow-up, all the SF-36 parameter decreased to the baseline values [119].

In 2012 published randomised, single-blind, follow-up study, Tefner et al compared the effects of 15 sessions of balneotherapy with tap water in outpatients with low back pain. Assessments were undertaken at baseline, week 3, week 6 and week 13. By the end of the balneotherapy course, the VAS score of low back pain, mobility of the lumbar spine (reflected by lumbar Schober's sign and lateral flexion in both directions) and Oswestry Disability Index, EuroQol-5D index, all components of the SF-36 questionnaire (except for the components 
indicative of general health and social functioning) improved significantly in the treatment group, compared to baseline. These improvements persisted until the end of follow-up. By contrast, no significant changes occurred in the control group. Between-group differences in the above parameters were significant both at the end of balneotherapy and during follow-up. In the treatment group, the consumption of analgesics and NSAIDs necessary to relieve chronic low back pain decreased significantly by the end of balneotherapy, and this reduction remained significant until the end of follow-up [120]. Their study is well comparable with our trial in treatment duration and similar outcome parameters. Although a much greater improvement was observed in their study than in ours, it can be attributed in part to the high mineral content of the applied thermal-mineral water and in part to the single-blind design of the study.

Also in 2012 published paper, Kesiktas et al compared the effect of combined physical therapy (transcutaneous electrical nerve stimulation, ultrasound, infrared radiation combined with back education program and exercise) with balneotherapy and same back education, and exercise programs. Significant improvements in back extensor muscle test, lumbar flexibility (Schober's test), functional capacity (ODI), and quality of life (SF-36) and reduction in pain severity were found in both groups. These effects persisted even improved in spa therapy group 3 months later but this was not significantly different than physiotherapy group. Comparing the two groups at 3month spa therapy had significant superiority to physical therapy in improving quality of life and flexibility of patients [121]. Gremeaux et al in a randomized prospective alternate-month designtype study recruited 360 outpatients with chronic low back pain. Intervention group underwent a spa therapy program for 3 weeks including 15 sessions of mud pack at $45{ }^{\circ} \mathrm{C}$ for 20 min, supervised mobilization in a mineral water pool at $33{ }^{\circ} \mathrm{C}, 15 \mathrm{~min}$, and waterspouts in the pool 10 min, and hydrojet 10 min 5 days/week combined with three standardized education workshops every week lasting an hour and a half each. Control group had same spa therapy and nonstandardized verbal information. According to the results they found a significant reduction in the physical fear avoidance beliefs score at 6 months in both study groups, and this reduction was more marked in the spa therapy group including education workshops. Disability (Quebec Scale) and pain intensity significantly decreased in both groups, with no difference between groups [122].

Our study compared thermal water with tap water, and not with pharmacotherapy of other treatment modalities. By doing so, medicinal water containing mineral solutes was shown to be a more effective treatment than tap water, which exerts physical only effects. 
Table 3. Statistical analvsis of changes over 3 and 15 weeks, compared to baseline: comparison of the nature of changes and of treatment groups Baseline Changes observed after 3 weeks Changes observed after 15 weeks

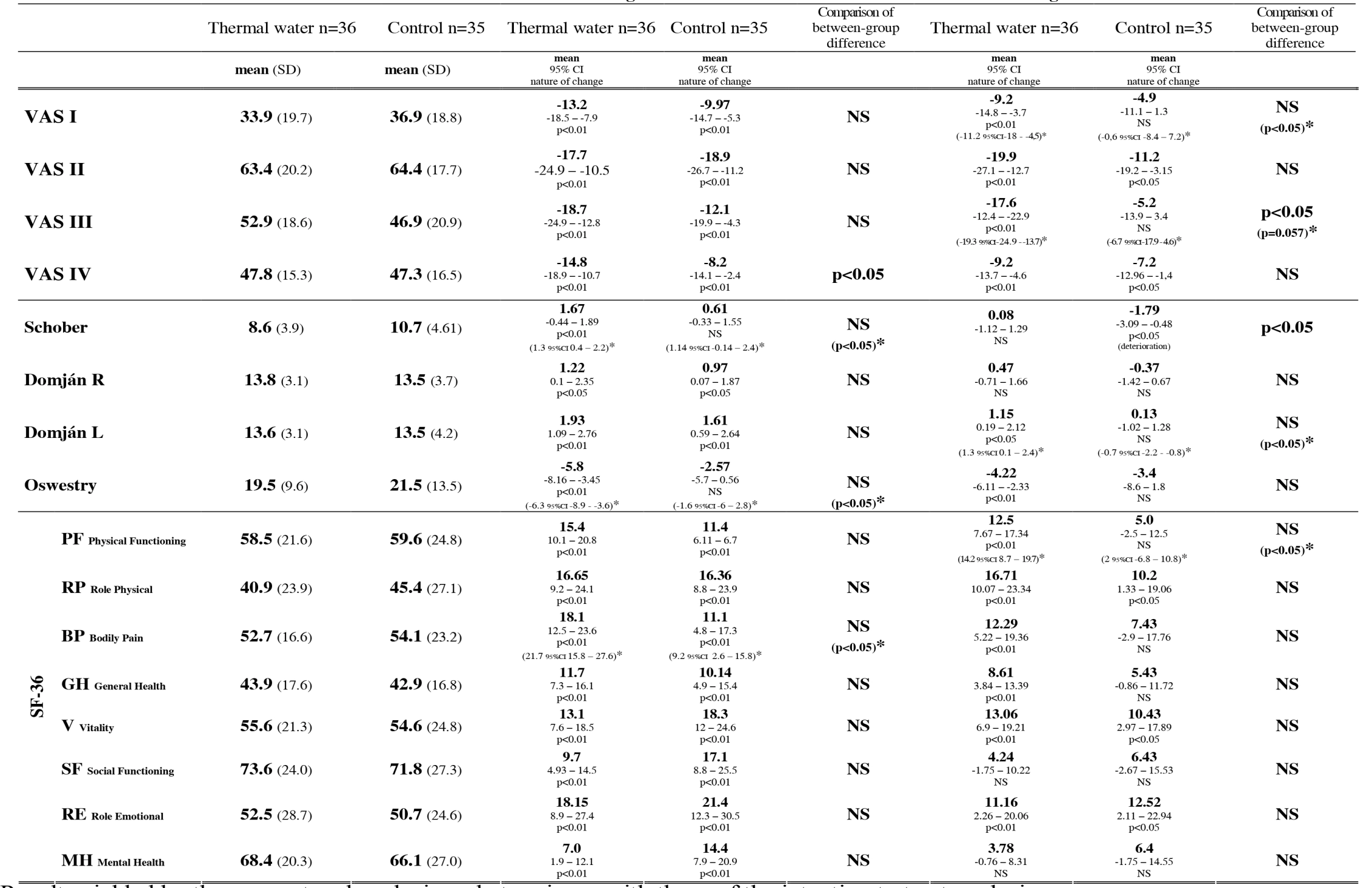

Results yielded by the per protocol analysis and at variance with those of the intention to treat analysis. 


\section{EVALUATION OF THE EFFECT OF BALNEOTHERAPY IN PATIENTS WITH OSTEOARTHRITIS OF THE HANDS, A SINGLE-BLIND, RANDOMIZED, CONTROLLED FOLLOW-UP STUDY}

This trial was performed in co-operation and under shared lead authorship with Katalin Horváth. Katalin Horváth as former rheumatologist at Gunarasfürdő was responsible for patient enrollment and coordination. I acted as independent investigator in the trial; this publication has been jointly prepared by both of us.

\section{OBJECTIVES}

There have been several publications about the use of balneotherapy in osteoarthritis. The majority of these publications describe the treatment of knee osteoarthritis. Therapeutic recommendations mention a broad scale of non-pharmacological conservative treatment options. Our primary objective was to evaluate how Gunaras thermal mineral water therapy influences pain, hand function and quality of life in patients with hand osteoarthritis compared with the control group. The secondary objective of the study was to evaluate whether different water temperatures influence clinical parameters.

\section{MATERIALS AND METHODS}

\section{Design}

This was a randomized single-blind three-arm parallel-group controlled follow-up study. It was conducted in accordance with the Declaration of Helsinki, International Conference on Harmonization - good clinical practice standards and was approved by the Regional Research Ethics Committee (Approval No. 316-25031/KK41/2009).

\section{Participants}

All subjects were informed about the purpose, conditions and course of the study prior to inclusion. Patients have read and understood the Patient Information Sheet and have signed the Informed Consent Form. The study was planned and conducted in accordance with the guidelines of the Osteoarthritis Research Society International [123] regarding hand osteoarthritis. Male and female patients between 50 and 70 years of age with moderate to mild osteoarthritis of the hands meeting the American College of Rheumatology classification criteria regarding hand osteoarthritis that has been confirmed by radiological assessments (comparative radiograph of the 
hands) and who have hand pain characteristic of osteoarthritis of the hands for at least three months [124] were included in the study. Patients with the following diseases or conditions were excluded from the study: conditions or diseases contraindicating hot bath treatment, every severe diseases affecting the internal organs, the urogenital tract or the skin, infection or fever when bath treatment is contraindicated; non-steroid anti-inflammatory or chondroprotective therapy that was changed within one month prior to the initiation of study treatment or during study treatment; intraarticular corticosteroid injection administered within one month prior to the initiation of study treatment or during study treatment; inflammatory rheumatic disease (rheumatoid arthritis, ankylosing spondylitis, psoriatic arthritis, crystal arthropathy, etc.) or carpal tunnel syndrome, tenosynovitis or fibromyalgia syndrome; hand injury or hand surgery within six months prior to the study; and any fractures of the hand. Also excluded were non-cooperative patients and patients with inadequate mental or psychic condition. Patients who had received any kind of physical therapy during the three-month period prior to the study were also excluded.

\section{Study procedures}

The study site was Gunaras bath, located $2 \mathrm{~km}$ from Dombóvár, a small West Transdanubian town in Hungary. Recruitment of patients started in February 2010, whereas the study was launched at the end of May 2010. Patients were enrolled by the rheumatologist of Gunaras Health Spa from the population visiting the rheumatology specialist clinic of Gunaras Health Spa or from patients referred to the spa by general practitioners who received an information leaflet about the study. Enrollment was in conformity with the inclusion and exclusion criteria. The patients were examined by an independent rheumatologist. Enrolled patients completed the balneotherapy treatment as outpatients, with no change in their daily routine or work attendance. The patients were monitored continuously during the treatment sessions. Patients completing more than $80 \%$ of the treatments were considered to have completed the study. Baseline and post-balneotherapy assessments were performed by an independent rheumatologist. Patients were randomized into three treatment groups. All three groups received standard pulsed magnetic field therapy $(60 \mathrm{~Hz}, 20 \mathrm{~J}, 15$ minutes) applied on the hands three times weekly for three weeks. In addition, the patients in two groups bathed by immersion of the body (head-out immersion) in $36^{\circ} \mathrm{C}$ or $38^{\circ} \mathrm{C}$ thermal mineral water (group 1 and group 2, respectively). The subjects in these groups underwent 20 minutes balneotherapy sessions five times weekly for three weeks. 


\section{Randomization and blinding}

The patients were randomly assigned into three groups following simple randomization with a computer-generated sequence. The randomizer was not involved in the implementation of the study. The randomizer received the information about the patients by via mail. Corresponding envelopes were opened only after the enrolled participants completed all baseline assessments and it was time to allocate the intervention. The professional performing the statistical analysis was aware of the randomization. The examiner was blinded regarding the received therapy.

\section{Evaluations}

The primary outcome measures were visual analogue scale scores, handgrip strength, pinchgrip strength, the number of swollen and tender joints of the hand, the duration of morning joint stiffness, HAQ and SF-36 questionnaire. The subjects were assessed three times: at baseline, after three weeks and after 13 weeks. A 100mm VAS was used to record the pain in small joints of the hand, as follows: VAS I: the severity of pain in the small joints of the hands at rest, as rated by the patient. VAS II: the severity of pain in the small joints of the hands upon exertion, as rated by the patient. VAS III: patient's global assessment of hand status. VAS IV: physician's global assessment of hand status. For both hands, grip strength and two podpinch strength (thumb and index finger) were measured in kilograms by the Saehan Hydraulic Hand Dynamometer (Model SH5001) with the subjects sitting in a standard position with the elbow in $90^{\circ}$ flexion and the wrist in a neutral position [125]. The mean of the five registrations was recorded. The number of swollen and tender joints and the duration of morning stiffness of the small joints of the hands were recorded. The HAQ was used to assess the function of the hand. The subjects' quality of life was evaluated with the SF-36 questionnaire. We presented from the SF-36 subscales the normbased physical component summary (PCS) and mental component summary (MCS) scores.

\section{Thermal water composition}

The thermal mineral water is an alkaline sodium hydrogen carbonate containing soft water that contains significant amounts of fluoride. Its total mineral content was $2210 \mathrm{mg} / \mathrm{L}$, its temperature was $36^{\circ} \mathrm{C}$ in one group (group 1) and $38^{\circ} \mathrm{C}$ in the other group (group 2). The characteristics and mineral composition of the thermal water are shown in Table 4. 
Table 4. Characteristics and mineral composition of thermal water

\begin{tabular}{llll}
\hline \hline \multicolumn{2}{l}{ Total solute mineral } & $2110 \mathrm{mg} / \mathrm{l}$ & \\
\multicolumn{2}{l}{ Total organic content } & $3.1 \mathrm{mg} / 1$ & \\
\multicolumn{2}{l}{ Total hardness of water } & $11.0 \mathrm{CaO} \mathrm{mg} / 1$ & \\
$\mathbf{p H}$ & 8.0 & \\
$\mathbf{W a t e r}$ & & & \\
Wemperature & $\mathbf{m g} / \mathbf{l}$ & $36^{\circ} \mathrm{C} / 38^{\circ} \mathrm{C}$ & \\
\hline Cations & Anions & $\mathbf{m g} / \mathbf{l}$ \\
\hline Sodium & 610 & Chlorine & 72 \\
Potassium & 5 & Bromine & 0.707 \\
Ammonium & 8.8 & Idine & 0.16 \\
Calcium & 4.1 & Fluorine & 2.96 \\
Magnesium & 0.8 & Sulphate & 27 \\
Iron & 0.05 & Hydrogen carbonate & 1403 \\
Lithium & 0.07 & Sulphide & 0.18 \\
\hline \hline
\end{tabular}

\section{Statistical analysis}

Data were entered into and analysed with MS Excel and SPSS software. Statistical comparisons were made using ANOVA and as post-hoc tests Scheffe' and Dunnett. Intention-to-treat (ITT) analysis was performed. Probability (p) values below 0.05 were considered significant.

\section{RESULTS}

Of the 63 patients included in the study, 59 completed more than $80 \%$ of the therapy course. Demographic and baseline clinical characteristics of patients are shown in Table 5.

Table 5. Demographic data and other baseline clinical characteristics of the patients by treatment group

\begin{tabular}{lccc}
\hline \hline & Thermal water $\mathbf{3 6}^{\circ} \mathbf{C}$ & Thermal water38 ${ }^{\circ} \mathbf{C}$ & Control \\
\hline Enrolled, male/female & $\mathrm{n}=21,4 / 17$ & $\mathrm{n}=21,5 / 16$ & $\mathrm{n}=21,3 / 18$ \\
\cline { 2 - 3 } BMI & Mean (SD) & Mean (SD) & Mean (SD) \\
\cline { 2 - 3 } Age & $29.4(3.5)$ & $26.9(4.1)$ & $28.9(5.4)$ \\
Duration of symptoms (years) & $63.5(4.7)$ & $62.3(4.8)$ & $63.8(4.4)$ \\
Right-handed/left-handed & $16.4(12.7)$ & $10.3(11.6)$ & $11.7(9.9)$ \\
\hline VAS I & $20 / 1$ & $20 / 1$ & $20 / 0$ \\
VAS II & $34.8(20.7)$ & $29.7(22.8)$ & $31.9(23.8)$ \\
VAS III & $57.8(22.9)$ & $54.8(24.6)$ & $51.9(23.8)$ \\
VAS IV & $50.4(15.0)$ & $48.5(19.4)$ & $47.6(20.2)$ \\
Grip strength right hand $(\mathrm{kg})$ & $46.1(15.1)$ & $49.8(17.8)$ & $42.8(15.7)$ \\
Grip strength left hand $(\mathrm{kg})$ & $17.5(7.5)$ & $21.4(11.5)$ & $17.3(8.1)$ \\
Pinch strength right hand $(\mathrm{kg})$ & $15.9(7.4)$ & $19.4(10.7)$ & $15.3(8.1)$ \\
Pinch strength left hand $(\mathrm{kg})$ & $2.9(1.5)$ & $3.3(2.5)$ & $2.9(1.2)$ \\
HAQ & $2.7(1.1)$ & $2.96(1.7)$ & $2.4(1.1)$ \\
Morning joint stiffness (min) & $1.0(0.4)$ & $0.99(0.5)$ & $0.8(0.5)$ \\
Swollen joint count & $9.7(7.9)$ & $12.4(17.2)$ & $9.4(8.6)$ \\
Tender joint count & $3.0(2.1)$ & $3.4(2.6)$ & $2.1(2.3)$ \\
\hline SF-36 PCS (Physical Component Summary) & $7.1(4.9)$ & $8.3(4.4)$ & $5.5(4.5)$ \\
\hline MCS (Mental Component Summary) & $37.4(6.6)$ & $37.5(6.1)$ & $39.7(6.7)$ \\
\hline \hline
\end{tabular}


The treatment groups were similar with regard to demographic data and baseline clinical characteristics. All study patients except two were right-handed. Four patients discontinued the treatment period after three weeks (two patients in the thermal group I $\left(36^{\circ} \mathrm{C}\right)$, and two patients in the control group). The disposition of the patients is presented in Figure 2.

Figure 2. Disposition of the patients

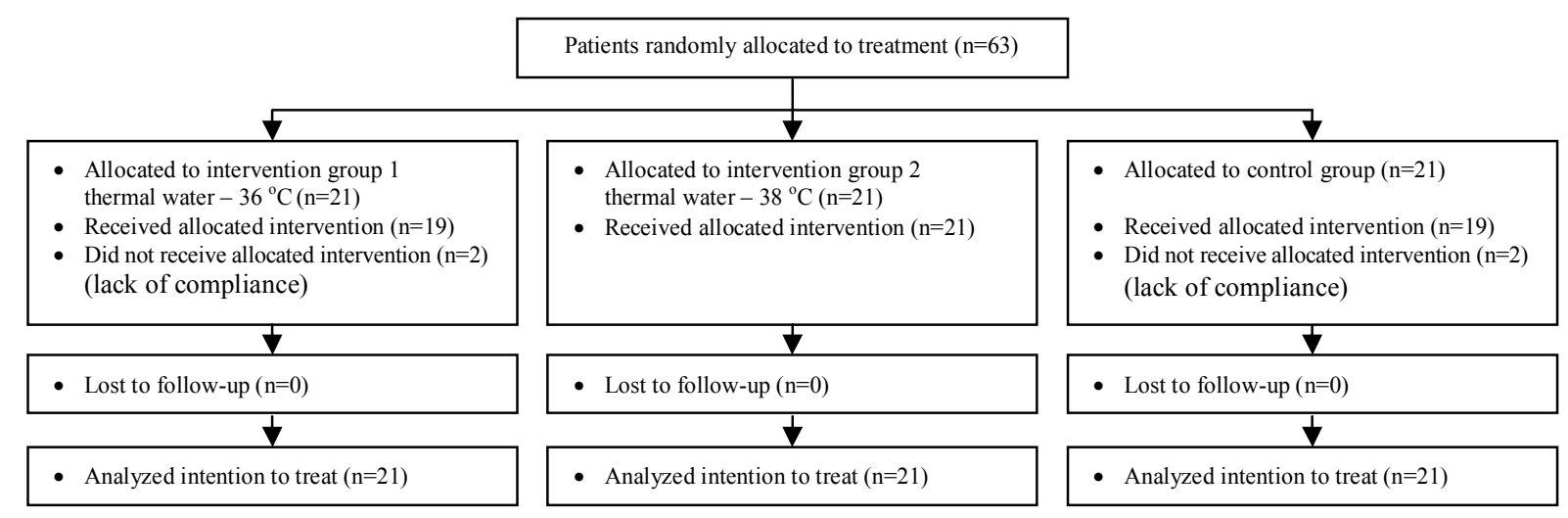

Examination of the hands revealed an improvement in the subjective parameters measured by VAS scale in all study groups. After the three-week treatment, patients receiving $36^{\circ} \mathrm{C}$ thermal water therapy showed a significant therapeutic response compared with the control group, with a decrease in VAS I (-28.9 (95\% CI -38.2 to -19.5) vs. 11.4 (95\% CI -19.1 to -3.8$), \mathrm{p}<0.05)$ and VAS II (-28.2 (95\% CI 36.5 to -19.9$)$ vs.-9.95 (95\% CI -20.1 to 0.2$)$, $\mathrm{p}<0.05)$ scores. In patients treated with $38^{\circ} \mathrm{C}$ water, VAS IV score showed a similar statistical effect compared with the control group $(-14.6 \quad(95 \%$ CI -19.9 to -9.2$)$ vs. -3.0 (95\% CI -5.9 to -0.1$), \mathrm{p}<0.01)$. During the follow-up period, long-term improvement was seen in the VAS I ( -20.3 (95\% CI -28.9 to -11.6$)$ vs. -4.8 (95\% CI -9.8 to 0.2$), p<0.05)$ and VAS IV (-7.9 (95\% CI -11.96 to -3.9$)$ vs. -0.1 (95\% CI -3.7 to 3.6$), \mathrm{p}<0.05)$ parameters of the $36^{\circ} \mathrm{C}$ thermal water group and in the VAS III $(-19.0$ (95\% CI -27.5 to -10.5$)$ vs. $-4.1(95 \%$ CI -10.6 to 2.4$), \mathrm{p}<0.05)$ and VAS IV ( -15.3 (95\% CI -20.0 to -10.7$)$ vs. -0.1 (95\% CI -3.7 to 3.6$), \mathrm{p}<0.01$ ) scores of the $38^{\circ} \mathrm{C}$ thermal water group compared with control. Remarkable and long-term improvement was noted in the grip and pinch strengths of both hands in the thermal water groups at all study time points. By the end of week 3, the grip strength of the right hand significantly improved in patients treated with $36^{\circ} \mathrm{C}$ thermal water compared with the control group (3.8 (95\% CI 0.8 to 6.8 ) vs. -0.1 (95\% CI -1.5 to 1.3 ), 
$\mathrm{p}<0.05$ ). No significant difference was seen between the thermal water-treated and control groups at other study time points. In patients receiving $38^{\circ} \mathrm{C}$ thermal water therapy, pinch strength of the dominant right hand with the control group (0.7 (95\% CI 0.3 to 1.1$)$ vs. 0.1 (95\% CI -0.1 to 0.3 ), $\mathrm{p}<0.05$ ). This significant improvement lasted even during the follow-up period (0.6 (95\% CI 0.2 to 1.1$)$ vs. 0.03 ( $95 \%$ CI -0.3 to 0.4$), p<0.05)$. Improvement of the HAQ index was significant only in the $38^{\circ} \mathrm{C}$ thermal water-treated group both after treatment (-0.5 (95\% CI -0.7 to -0.3$)$ vs. $-0.1(95 \%$ CI -0.2 to 0.04$), \mathrm{p}<0.01)$ and during the follow-up period $(-0.4(95 \%$ CI -0.6 to -0.2$)$ vs. $-0.1(95 \%$ CI -0.2 to 0.1$), p<0.01)$ compared with the control group. Decrease of morning joint stiffness was detectable in all groups. However, no significant differences were found between the treated and control groups at any of the time points studied. The number of swollen joints significantly decreased in the thermal water groups compared with the control group at both time points studied (-1.9 (95\% CI -2.8 to -1.0$),-1.9(95 \% \mathrm{CI}-2.7$ to -1.1$)$ vs. $-0.2(95 \% \mathrm{CI}-0.5$ to 0.2$), \mathrm{p}<0.01) ;-1.9(95 \% \mathrm{CI}-2.8$ to -0.95$),-2.0(95 \% \mathrm{CI}-2.8$ to -1.2$)$ vs. $0.2(95 \% \mathrm{CI}-0.3$ to 0.8$), \mathrm{p}<0.01)$.

A substantial and significant decrease was seen in the number of tender joints in the thermal water groups after treatment (-4.2 (95\% CI -6.2 to -2.3$),-5.1$ (95\% CI -6.95 to -3.3$)$ vs. $-0.4(95 \%$ CI -1.1 to 0.4$), p<0.01)$ and during follow up (-3.95 (95\% CI -5.8 to -2.1$),-5.3$ $(95 \% \mathrm{CI}-7.2$ to -3.5$)$ vs. $-0.1(95 \% \mathrm{CI}-0.8$ to 0.5$), \mathrm{p}<0.01)$ compared with the control group.

The SF-36 health survey questionnaire documented a substantial and permanent improvement of physical component summary (PCS) scores in the thermal water-treated groups, right after the therapy and during the follow-up period. After the three-week treatment, this improvement was significantly better in the $38^{\circ} \mathrm{C}$ thermal water-treated group compared with control (6.3 (95\% CI 3.9 to 8.6$)$ vs. 2.0 (95\% CI 0.3 to 3.7$)$, p<0.05). Mental component summary (MCS) scores improved only in the thermal water groups. After week 3, this improvement was significantly higher in the $36^{\circ} \mathrm{C}$ thermal water-treated group compared with control (4.8 (95\% CI 1.3 to 8.4$)$ vs. -0.5 (95\% CI -2.6 to 1.5$), \mathrm{p}<0.05)$. During follow-up, no significant improvements were noted in the PCS and MCS scores of the thermal watertreated groups compared with control.

Direct comparison of the effects of the $36^{\circ} \mathrm{C}$ and $38^{\circ} \mathrm{C}$ thermal waters revealed no significant differences in the treatment responses. The measured values, changes compared to the baseline and statistical data are presented in Table 6 . 


\section{DISCUSSION}

The aim of this study was to assess the effect of balneotherapy in patients with osteoarthritis of the hands. Our study is the first assessment of the efficacy of balneotherapy in this condition. Based on the results presented here, thermal water treatment was more effective in several subjective and objective outcome parameters compared with the control magnetotherapy group. It can be postulated that the thermal water at $38^{\circ}$ is more effective than that at $36^{\circ} \mathrm{C}$, since the $38^{\circ} \mathrm{C}$ water treatment significantly improved the pinch strength of the right hand and the HAQ parameters, even in the long term, whereas no significant changes were noted in the same parameters in the $36^{\circ} \mathrm{C}$ thermal water-treated group compared with control.

Mud treatment of small joints of the hands in patients with rheumatoid arthritis has decreased the pain intensity and the number of swollen and tender joints [126]. A contrast bath procedure applied to small hand joints increased body surface blood flow and skin temperature [127].

Low-frequency pulsed electromagnetic field (PEMF) therapy is frequently used to treat the symptoms of osteoarthritis [128]. It also can provide a non-invasive, safe and easy-to-apply method to treat pain, inflammation and dysfunctions associated with osteoarthritis [129].

The small improvements in the control group confirm the inconclusive effect of magnetotherapy (i.e. nine studies performed based on the analysis of the data of 483 patients with knee osteoarthritis revealed significant improvement only in quality of life but not in pain and joint stiffness); therefore, it is recommended as adjuvant therapy [130].

Positive effects of balneotherapy on quality of life were confirmed by a large Italian study, the Naiade Project. According to the results of the Naiade study, balneotherapy treatment significantly decreased the need for other treatments (hospitalization, physical and pharmaceutical therapy) and decreased loss of working hours in patients with osteoarthritis [131].

The current study had some limitations in addition to its small sample size. It remains to be determined whether the present results were due to the effects of balneotherapy alone or the combined effects of balneo- and magnetotherapy. Since no specific, validated Hungarian hand function tests are available, HAQ was used for the assessment of functional status of the hands. 
Table 6. Measured values, changes compared to the baseline, and statistical data of groups at various time points of the study

\begin{tabular}{|c|c|c|c|c|c|c|c|c|c|c|}
\hline & \multicolumn{5}{|c|}{ Assessment 2 (3 weeks later) } & \multicolumn{5}{|c|}{ Assessment 3 (13 weeks later) } \\
\hline & \multicolumn{3}{|c|}{ Changes compared to the baseline } & \multicolumn{2}{|c|}{ Group comparison } & \multicolumn{3}{|c|}{ Changes compared to the baseline } & \multicolumn{2}{|c|}{ Group comparison } \\
\hline & $\begin{array}{c}\text { Thermal water } \\
36{ }^{\circ} \mathrm{C}\end{array}$ & $\begin{array}{c}\text { Thermal water } \\
38^{\circ} \mathrm{C}\end{array}$ & Control & \multirow{2}{*}{$\begin{array}{c}\text { Thermal water } \\
36^{\circ} \mathrm{C}- \\
\text { Control }\end{array}$} & \multirow{2}{*}{$\begin{array}{l}\text { Thermal water } \\
38^{\circ} \mathrm{C}- \\
\text { Control }\end{array}$} & $\begin{array}{c}\text { Thermal water } \\
36^{\circ} \mathrm{C}\end{array}$ & $\begin{array}{c}\text { Thermal water } \\
38^{\circ} \mathrm{C}\end{array}$ & Control & \multirow{2}{*}{$\begin{array}{c}\text { Thermal water } \\
36^{\circ} \mathrm{C}- \\
\text { Control }\end{array}$} & \multirow{2}{*}{$\begin{array}{c}\text { Thermal water } \\
38^{\circ} \mathrm{C}- \\
\text { Control }\end{array}$} \\
\hline & $\begin{array}{l}\text { Mean } \\
95 \% \mathrm{CI} \\
\end{array}$ & $\begin{array}{l}\text { Mean } \\
95 \% \text { CI }\end{array}$ & $\begin{array}{l}\text { Mean } \\
95 \% \text { CI } \\
\end{array}$ & & & $\begin{array}{l}\text { Mean } \\
95 \% \mathrm{CI} \\
\end{array}$ & $\begin{array}{l}\text { Mean } \\
95 \% \text { CI } \\
\end{array}$ & $\begin{array}{l}\text { Mean } \\
95 \% \text { CI } \\
\end{array}$ & & \\
\hline VAS I & $\begin{array}{c}\mathbf{- 2 8 . 9} \\
-38.2 \text { to }-19.5\end{array}$ & $\begin{array}{c}\mathbf{- 2 1 . 5} \\
-29.8 \text { to }-13.2\end{array}$ & $\begin{array}{c}\mathbf{- 1 1 . 4} \\
-19.1 \text { to }-3.8\end{array}$ & $\mathbf{p}<0.05$ & NS & $\begin{array}{c}\mathbf{- 2 0 . 3} \\
-28.9 \text { to }-11.6\end{array}$ & $\begin{array}{c}\mathbf{- 1 7 . 7} \\
-26.2 \text { to }-9.2\end{array}$ & $\begin{array}{c}\mathbf{- 4 . 8} \\
-9.8 \text { to } 0.2\end{array}$ & $\mathbf{p}<0.05$ & NS \\
\hline VAS II & $\begin{array}{c}\mathbf{- 2 8 . 2} \\
-36.5 \text { to }-19.9\end{array}$ & $\begin{array}{c}\mathbf{- 2 3 . 2} \\
-31.9 \text { to }-14.6\end{array}$ & $\begin{array}{c}\mathbf{- 9 . 9 5} \\
-20.1 \text { to } 0.2\end{array}$ & $\mathbf{p}<0.05$ & NS & $\begin{array}{c}\mathbf{- 2 0 . 7} \\
-30.6 \text { to }-10.8\end{array}$ & $\begin{array}{c}\mathbf{- 2 3 . 8} \\
-33.3 \text { to }-14.3\end{array}$ & $\begin{array}{c}\mathbf{- 9 . 8} \\
-19.6 \text { to }-0.02\end{array}$ & NS & NS \\
\hline VAS III & $\begin{array}{c}-\mathbf{1 8 . 7} \\
-28.3 \text { to }-9.2\end{array}$ & $\begin{array}{c}\mathbf{- 1 7 . 9 5} \\
-25.7 \text { to }-10.3\end{array}$ & $\begin{array}{c}-\mathbf{6 . 5} \\
-11.3 \text { to }-1.6\end{array}$ & NS & NS & $\begin{array}{c}\mathbf{- 1 6 . 6} \\
-24.5 \text { to }-8.8\end{array}$ & $\begin{array}{c}\mathbf{- 1 9 . 0} \\
-27.5 \text { to }-10.5\end{array}$ & $\begin{array}{c}\mathbf{- 4 . 1} \\
-10.6 \text { to } 2.4\end{array}$ & NS & $\mathbf{p}<\mathbf{0 . 0 5}$ \\
\hline VAS IV & $\begin{array}{c}\mathbf{- 9 . 2} \\
-12.5 \text { to }-5.9\end{array}$ & $\begin{array}{c}\mathbf{- 1 4 . 6} \\
-19.9 \text { to }-9.2 \\
\end{array}$ & $\begin{array}{c}\mathbf{- 3 . 0} \\
-5.9 \text { to }-0.1 \\
\end{array}$ & NS & $\mathbf{p}<\mathbf{0 . 0 1}$ & $\begin{array}{c}-\mathbf{- 7 . 9} \\
-11.96 \text { to }-3.9 \\
\end{array}$ & $\begin{array}{c}\mathbf{- 1 5 . 3} \\
-20.0 \text { to }-10.7 \\
\end{array}$ & $\begin{array}{c}\mathbf{- 0 . 1} \\
-3.7 \text { to } 3.6 \\
\end{array}$ & $\mathbf{p}<0.05$ & $\mathbf{p}<\mathbf{0 . 0 1}$ \\
\hline $\begin{array}{l}\text { Grip strength } \\
\text { right hand (kg) }\end{array}$ & $\begin{array}{c}\mathbf{3 . 8} \\
0.8 \text { to } 6.8\end{array}$ & $\begin{array}{c}\mathbf{3 . 5} \\
1.2 \text { to } 5.8\end{array}$ & $\begin{array}{c}\mathbf{- 0 . 1} \\
-1.5 \text { to } 1.3\end{array}$ & $\mathbf{p}<0.05$ & NS & $\begin{array}{c}\mathbf{3 . 7} \\
-0.2 \text { to } 7.6\end{array}$ & $\begin{array}{c}\mathbf{4 . 0} \\
1.1 \text { to } 6.9\end{array}$ & $\begin{array}{c}\mathbf{0 . 3} \\
-1.4 \text { to } 1.9\end{array}$ & NS & NS \\
\hline $\begin{array}{l}\text { Grip strength } \\
\text { left hand (kg) }\end{array}$ & $\begin{array}{c}\mathbf{2 . 9 9} \\
0.4 \text { to } 5.6\end{array}$ & $\begin{array}{c}\mathbf{2 . 7} \\
0.8 \text { to } 4.7\end{array}$ & $\begin{array}{c}\mathbf{0 . 6} \\
-1.0 \text { to } 2.2\end{array}$ & NS & NS & $\begin{array}{c}\mathbf{2 . 7} \\
-0.3 \text { to } 5.6\end{array}$ & $\begin{array}{c}\mathbf{4 . 4} \\
1.4 \text { to } 7.3\end{array}$ & $\begin{array}{c}-\mathbf{- 0 . 1} \\
-1.7 \text { to } 1.5\end{array}$ & NS & NS \\
\hline $\begin{array}{l}\text { Pinch strength } \\
\text { right hand (kg) }\end{array}$ & $\begin{array}{c}\mathbf{0 . 6} \\
0.2 \text { to } 0.9\end{array}$ & $\begin{array}{c}\mathbf{0 . 7} \\
0.3 \text { to } 1.1\end{array}$ & $\begin{array}{c}\mathbf{0 . 1} \\
-0.1 \text { to } 0.3\end{array}$ & NS & $\mathbf{p}<0.05$ & $\begin{array}{c}\mathbf{0 . 4} \\
0.1 \text { to } 0.7\end{array}$ & $\begin{array}{c}\mathbf{0 . 6} \\
0.2 \text { to } 1.1\end{array}$ & $\begin{array}{c}\mathbf{0 . 0 3} \\
-0.3 \text { to } 0.4\end{array}$ & NS & $\mathbf{p}<0.05$ \\
\hline $\begin{array}{l}\text { Pinch strength } \\
\text { left hand (kg) }\end{array}$ & $\begin{array}{c}\mathbf{0 . 3} \\
0.1 \text { to } 0.5\end{array}$ & $\begin{array}{c}\mathbf{0 . 6} \\
0.3 \text { to } 0.9\end{array}$ & $\begin{array}{c}\mathbf{0 . 3} \\
0.1 \text { to } 0.5\end{array}$ & NS & NS & $\begin{array}{c}\mathbf{0 . 3} \\
0.04 \text { to } 0.6\end{array}$ & $\begin{array}{c}\mathbf{0 . 4} \\
0.1 \text { to } 0.7\end{array}$ & $\begin{array}{c}\mathbf{0 . 1} \\
-0.1 \text { to } 0.4\end{array}$ & NS & NS \\
\hline HAQ & $\begin{array}{c}-\mathbf{- 0 . 2} \\
-0.4 \text { to }-0.1\end{array}$ & $\begin{array}{c}\mathbf{- 0 . 5} \\
-0.7 \text { to }-0.3\end{array}$ & $\begin{array}{c}-\mathbf{- 0 . 1} \\
-0.2 \text { to } 0.04\end{array}$ & NS & $\mathbf{p}<\mathbf{0 . 0 1}$ & $\begin{array}{c}\mathbf{- 0 . 2} \\
-0.5 \text { to }-0.03\end{array}$ & $\begin{array}{c}-\mathbf{- 0 . 4} \\
-0.6 \text { to }-0.2\end{array}$ & $\begin{array}{c}\mathbf{- 0 . 1} \\
-0.2 \text { to } 0.1\end{array}$ & NS & $\mathbf{p}<\mathbf{0 . 0 1}$ \\
\hline $\begin{array}{l}\text { Morning joint } \\
\text { stiffness (min) }\end{array}$ & $\begin{array}{c}\mathbf{- 5 . 4} \\
-7.9 \text { to }-2.9\end{array}$ & $\begin{array}{c}\mathbf{- 8 . 1} \\
-13.9 \text { to }-2.2\end{array}$ & $\begin{array}{c}\mathbf{- 1 . 7} \\
-4.4 \text { to } 1.1\end{array}$ & NS & NS & $\begin{array}{c}-\mathbf{4 . 7} \\
-7.3 \text { to }-2.1\end{array}$ & $\begin{array}{c}-\mathbf{- 6 . 6} \\
-11.5 \text { to }-1.6\end{array}$ & $\begin{array}{c}\mathbf{- 1 . 2} \\
-2.3 \text { to }-0.1\end{array}$ & NS & NS \\
\hline $\begin{array}{l}\text { Swollen } \\
\text { joint count }\end{array}$ & $\begin{array}{c}\mathbf{- 1 . 9} \\
-2.8 \text { to }-1.0\end{array}$ & $\begin{array}{c}\mathbf{- 1 . 9} \\
-2.7 \text { to }-1.1\end{array}$ & $\begin{array}{c}\mathbf{- 0 . 2} \\
-0.5 \text { to } 0.2\end{array}$ & $\mathbf{p}<0.01$ & $\mathbf{p}<\mathbf{0 . 0 1}$ & $\begin{array}{c}\mathbf{- 1 . 9} \\
-2.8 \text { to }-0.95\end{array}$ & $\begin{array}{c}-\mathbf{2 . 0} \\
-2.8 \text { to }-1.2\end{array}$ & $\begin{array}{c}\mathbf{0 . 2} \\
-0.3 \text { to } 0.8\end{array}$ & $\mathbf{p}<\mathbf{0 . 0 1}$ & $\mathbf{p}<0.01$ \\
\hline $\begin{array}{l}\text { Tender } \\
\text { joint count }\end{array}$ & $\begin{array}{c}\mathbf{- 4 . 2} \\
-6.2 \text { to }-2.3\end{array}$ & $\begin{array}{c}\mathbf{- 5 . 1} \\
-6.95 \text { to }-3.3\end{array}$ & $\begin{array}{c}\mathbf{- 0 . 4} \\
-1.1 \text { to } 0.4\end{array}$ & $\mathbf{p}<\mathbf{0 . 0 1}$ & $\mathbf{p}<\mathbf{0 . 0 1}$ & $\begin{array}{c}\mathbf{- 3 . 9 5} \\
-5.8 \text { to }-2.1\end{array}$ & $\begin{array}{c}\mathbf{- 5 . 3} \\
-7.2 \text { to }-3.5\end{array}$ & $\begin{array}{c}\mathbf{- 0 . 1} \\
-0.8 \text { to } 0.5\end{array}$ & $\mathbf{p}<\mathbf{0 . 0 1}$ & $\mathbf{p}<\mathbf{0 . 0 1}$ \\
\hline \multirow{2}{*}{ SF 36} & $\begin{array}{c}\mathbf{5 . 5} \\
2.7 \text { to } 8.2\end{array}$ & $\begin{array}{c}\mathbf{6 . 3} \\
3.9 \text { to } 8.6\end{array}$ & $\begin{array}{c}\mathbf{2 . 0} \\
0.3 \text { to } 3.7\end{array}$ & NS & $\mathbf{p}<0.05$ & $\begin{array}{c}\mathbf{5 . 1} \\
1.8 \text { to } 8.5\end{array}$ & $\begin{array}{c}\mathbf{4 . 9} \\
2.2 \text { to } 7.7\end{array}$ & $\begin{array}{c}\mathbf{1 . 8} \\
-0.6 \text { to } 4.3\end{array}$ & NS & NS \\
\hline & $\begin{array}{c}\mathbf{4 . 8} \\
1.3 \text { to } 8.4\end{array}$ & $\begin{array}{c}\mathbf{4 . 2} \\
1.2 \text { to } 7.2\end{array}$ & $\begin{array}{c}-\mathbf{- 0 . 5} \\
-2.6 \text { to } 1.5\end{array}$ & $\mathrm{p}<\mathbf{0 . 0 5}$ & NS & $\begin{array}{c}\mathbf{1 . 7} \\
-2.3 \text { to } 5.7\end{array}$ & $\begin{array}{c}\mathbf{3 . 4} \\
0.8 \text { to } 6.0\end{array}$ & $\begin{array}{c}-\mathbf{- 0 . 1} \\
-1.9 \text { to } 1.7\end{array}$ & NS & NS \\
\hline
\end{tabular}




\section{EVALUATION OF THE EFFECT OF LAKE HÉVÍZ THERMAL MINERAL WATER IN PATIENTS WITH OSTEOARTHRITIS OF THE KNEE, A SINGLE- BLIND, RANDOMIZED, CONTROLLED FOLLOW-UP STUDY}

\section{OBJECTIVES}

Studies involving patients with knee osteoarthritis and systematic reviews confirmed the analgesic and knee function improving effect of balneotherapy as well as its positive influence on quality of life. However, in most of the studies, bath therapy was combined with other therapies (exercise program, massage, showers, mud therapy) [86,87,132,133]. Furthermore, only a limited number of previous studies covered the assessment of quality of life. Therefore, the primary endpoint of the study was the evaluation and documenting of the pain-reducing effect of Lake Hévíz thermal mineral water on knee pain at rest or on exertion in patients with mild to moderate knee osteoarthritis as well as the assessment of the therapeutic effect compared to the control group treated with warmed tap water. The secondary endpoints included the evaluation of the effect of Lake Hévíz thermal mineral water on knee function and quality of life.

\section{MATERIALS AND METHODS}

\section{Design}

This was a randomized, single-blind, controlled, parallel-group, follow-up study. The study was conducted in accordance with the Declaration of Helsinki, International Conference on Harmonization / Good Clinical Practice standards and was approved by the Regional Research Ethics Committee (Approval No. 18/2011).

\section{Participants}

This study included male and female patients between 45 and 75 years of age with mild to moderate, bilateral primary osteoarthritis of the knee (meeting the American College of Rheumatology knee osteoarthritis classification criteria [134]) diagnosed and documented with imaging techniques (comparative knee radiograph not older than 2 years). Patients had been suffering from knee pain characteristic for osteoarthritis for at least 3 months.

Exclusion criteria were conditions and diseases excluding warm water bath treatment (patients suffering from any severe internal, rheumatic, urogenital, or skin disorders or mental 
illnesses, which contraindicates bath treatment). Intraarticular corticosteroid injection within 1 month prior to the start of treatment, intraarticular hyaluronic acid therapy within 6 months prior to the initiation of treatment. Physiotherapy within 3 months prior to the start of treatment. Any change in nonsteroidal anti-inflammatory therapy or chondroprotective therapy within 1 month prior to treatment. Patients suffering from inflammatory rheumatic diseases (rheumatoid arthritis, ankylosing spondylitis, psoriatic arthritis, crystal arthropathies, etc.), patients with palpable fluid in the knee. Knee surgery within 6 months prior to the study; presence of metal implant in the knee joint. Patients with any previous fractures in the knee area, and/or knee injury within 6 months prior to the study. Patients with hip or spinal surgery within a year preceding the study. Patients with radiculopathy.

\section{Study procedures}

The study took place at Spa Hévíz and St. Andrew Hospital for Rheumatic Diseases (H-8380 Hévíz, Dr. Schulhof Vilmos sétány 1, Hungary), from May 2012 to August 2012. After verbal agreement, the physician of the Rheumatology Outpatient Clinic of Keszthely City Hospital and the rheumatologists of our Institute invited the patients to join the study, bearing in mind the inclusion and exclusion criteria. The enrolled patients received the treatment in an outpatient setting and they were able to continue their daily activities and work. The specialists of our Institute and the members of the Lake Hévíz Emergency Medicine Team were constantly available during the treatment for the management of side effects and problems emerging during treatment. Before enrollment, study participants were informed verbally and in writing about the purpose of the study and the study procedures. Prior to enrollment, patients read the Patient Information Sheet and signed the Informed Consent Form.

Patients were randomized into one of the two treatment groups. One group was treated in a covered area of Lake Hévíz and the control group was treated in a (1.2 to $1.4 \mathrm{~m}$ deep) pool bath filled with tap water of the same temperature as that of the thermal water. During the study, the temperature of the lake bath $\left(34^{\circ} \mathrm{C}\right)$ was the same as that of the pool bath. Patients received Lake Hévíz or pool bath treatment for 30 minutes 5 days a week, a total of 15 times. Patients were asked not to swim during bathing.

In order to follow up the patients, they were constantly under supervision during the treatment. Patients were considered as having completed the study if they participated in more 
than $80 \%$ of the treatment sessions. Patients did not receive any other physiotherapy in addition to the bath therapy. Further balneo/physiotherapy treatment, intraarticular corticosteroid or hyaluronic acid therapy, arthroscopic surgery, any change in nonsteroidal anti-inflammatory therapy or chondroprotective therapy was not allowed during the study and follow-up. Participants were evaluated just before treatment (Week 0), after the end of treatment (Week 3), and during the follow-up visit (Week 15). Patients were examined by seven rheumatologists. Before the study, the study personnel standardized and practiced joint assessment two times on patients not participating in the study. Patients randomized into the control group were given the opportunity to bath in the lake for free 15 times after the followup visit.

\section{Randomization and blinding}

Patients were randomly assigned into two groups following simple randomization with a computer-generated sequence. The randomizer was not involved in the conduction of the study. The randomizer received the information about the patients in e-mail. The person performing the statistical analysis did not participate in the randomization process. After randomization an independent person assigned the participants to the appropriate groups. Baseline and post-therapy assessments were performed by rheumatologists. The same patient was examined by the same physician every time. The examiners were blinded regarding the received therapy. Patients were told not to inform the study doctor about whether they received balneotherapy in Lake Hévíz or in the pool.

\section{Evaluations}

Characteristics of knee pain and condition were assessed on a $0-100 \mathrm{~mm}$ scale as follows: VAS I: knee pain at rest, as rated by the patient. VAS II: knee pain on exertion, as rated by the patient. VAS III: condition of the knee, as rated by the patient. VAS IV: condition of the knee, as rated by the investigator. WOMAC index was used to characterize knee joint pain, joint stiffness, and physical function. Angle of knee flexion on the left and right side measured by a goniometer (angle). Knee circumference $(\mathrm{cm})$. Stair-climb time in seconds to walk up 22 stairs in the pool bath building of the Hospital. EQ-5D a self-report questionnaire for the measurement of general health-related quality of life. 


\section{Thermal water composition}

The thermal mineral water of Lake Hévíz is rich in dissolved and gas components, thereby it combines the favorable characteristics of carbonate, sulfur, calcium, magnesium, hydrogen carbonate and very light radon-containing waters. The characteristics and mineral composition of Lake Hévíz water are shown in Table 7.

Table 7. Characteristics and mineral composition of Lake Hévíz water

\begin{tabular}{llll}
\hline \hline $\begin{array}{l}\text { Total hardness of water } \\
\text { pH }\end{array}$ & $\begin{array}{l}198 \mathrm{CaO} \mathrm{mg} / \mathrm{l} \\
7.14\end{array}$ \\
Water temperature & \multicolumn{2}{l}{$\begin{array}{l}\text { in summer: } 32-35^{\circ} \mathrm{C} \text {, in winter } 24-26^{\circ} \mathrm{C} \\
\text { covered lake bath in which the study was } \\
\text { conducted: } 32 \text { to } 34^{\circ} \mathrm{C}\end{array}$} \\
\hline Cations & $\mathbf{m g} / \mathbf{l}$ & Anions & $\mathbf{m g} \mathbf{l}$ \\
\hline Sodium & 21.7 & Chlorine & 25 \\
Potassium & 6.45 & Bromine & 0.11 \\
Ammonium & 0.22 & Iodine & 0.021 \\
Calcium & 82.1 & Fluorine & 1.18 \\
Magnesium & 36 & Sulphate & 63 \\
Iron & 0.24 & Hydrogen carbonate & 384 \\
Lithium & 0.07 & Sulphide & 3.2 \\
\hline Sum. & 151 & & 470 \\
\hline Others & mud, radon, meta borid acid, meta silica acid, organic acid, \\
\hline \hline
\end{tabular}

\section{Statistical analysis}

Sample size calculation was based on power analysis $(\alpha=0.05, \beta=0.80$, effect size $=0.65)$. Results were processed and evaluated in Microsoft Excel. For the statistical comparison of the samples, self-controlled and group-controlled methods: one-sample (paired) and two-sample t-tests were used. The analysis of the results was conducted by intention to treat. In order to avoid overestimation of the therapeutic effect, data from dropped-out patients were replaced by data of the last measurement. The level of significance was set at $\mathrm{p}<0.05$.

\section{RESULTS}

Of the 77 patients included in the study, 75 completed more than $80 \%$ of the therapy sessions. Demographic and baseline clinical characteristics of patients are shown in Table 8 . 
Table 8. Demographic data and other baseline clinical characteristics of the patients by treatment group

\begin{tabular}{lll}
\hline & Thermal water & Control \\
\hline Enrolled, male, female & $\mathrm{n}=38,8 / 30$ & $\mathrm{n}=39,9 / 30$ \\
\cline { 2 - 3 } Age & Mean (SD) & Mean (SD) \\
\cline { 2 - 3 } VAS I ${ }_{\text {at rest }}$ & $65.6(6.4)$ & $65.5(7.7)$ \\
VAS II on exertion $_{\text {VAS III }}$ patient's assessment & $33.6(23.4)$ & $33.2(21.8)$ \\
VAS IV physician's assessment & $55.2(20.2)$ & $58.0(20.9)$ \\
\hline$\quad$ Pain & $52.1(20.1)$ & $53.5(16.0)$ \\
Stiffness & $46.2(15.0)$ & $51.2(16.1)$ \\
\hline$\quad$ Function & $38.5(23.5)$ & $46.6(19.9)$ \\
\hline$\quad$ Flexion, right side & $49.4(26.9)$ & $51.2(20.6)$ \\
Flexion, left side & $43.4(21.7)$ & $44.5(17.8)$ \\
\hline$\quad$ Circumference, right side & $109.1(15.5)$ & $111.3(18.5)$ \\
$\quad$ Circumference, left side & $112.6(12.5)$ & $113.3(17.4)$ \\
\hline Stair-climb time & $40.4(3.7)$ & $40.9(4.3)$ \\
\hline EQ-5D & $40.3(3.8)$ & $40.7(4.5)$ \\
EQ-5D VAS & $20.3(3.6)$ & $21.9(5.1)$ \\
\hline \hline
\end{tabular}

Treatment groups were similar with regard to demographic data and baseline clinical characteristics. Two patients discontinued the treatment (1 patient in the thermal group and 1 patient in the control group). Two patients in the control group did not attend the Visit 3. Disposition of patients is presented in Figure 3.

Figure 3. Disposition of the patients

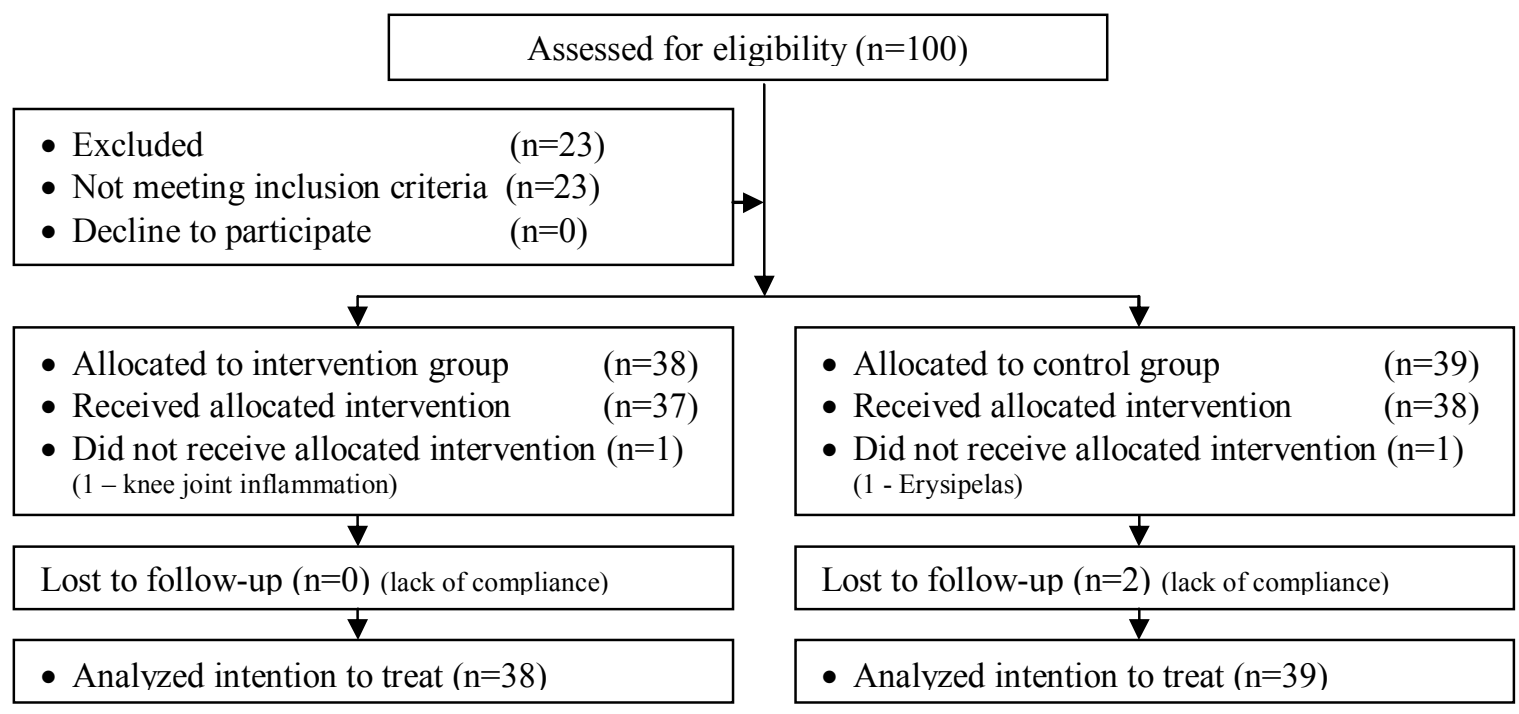


Examination of the knee revealed an improvement in the pain parameters measured by VAS scale in both study groups. After the 3-week treatment, patients receiving thermal water therapy showed a significant therapeutic response compared to the control group, with a decrease in VAS I (-21.1 (95\% CI -27.7 to -14.6$)$ vs. -3.7 (95\% CI -9.6 to -2.2$) \mathrm{p}<0.01)$, VAS II (-22.8 (95\% CI -27.1 to -18.5$)$ vs. $-6.8(95 \%$ CI -12.0 to -1.7$) \mathrm{p}<0.01)$, VAS III $(-21.7(95 \%$ CI -27.1 to -16.3$)$ vs. $-8.5(95 \%$ CI -13.1 to -3.9$) \mathrm{p}<0.01)$, and VAS IV $(-15.1(95 \%$ CI -18.6 to -11.5$)$ vs. $-8.0(95 \%$ CI -11.7 to -4.3$) \mathrm{p}<0.01)$ scores. During the follow-up period, long-term improvement was seen in all of the VAS scales: VAS I -18.8 (95\% CI -26.0 to -11.5$)$ vs. -2.8 (95\% CI -10.5 to 5.0) (p<0.01), VAS II -19.0 (95\% CI -25.6 to -12.4$)$ vs. $-2.4(95 \%$ CI -8.8 to 4.0$)(\mathrm{p}<0.01)$, VAS III -19.9 (95\% CI -27.1 to -12.8$)$ vs. -6.2 $(95 \%$ CI -11.0 to -1.3$)(\mathrm{p}<0.01)$, and VAS IV $-16.5(95 \%$ CI -21.3 to -11.7$)$ vs. $-5.6(95 \%$ CI -9.8 to -1.3$)(\mathrm{p}<0.01)$.

In the thermal water-treated group, all three dimensions of the WOMAC index (pain, joint stiffness, function) showed significant improvement after the treatment and during the follow-up period. Comparing the changes in the study groups, all three parameters of the WOMAC index showed significantly better improvement in the thermal water-treated group than in the control group: pain subscales -11.9 (95\% CI -16.7 to -7.1$)$ vs. -5.5 (95\% CI -9.5 to -1.6$)(\mathrm{p}<0.05)$, stiffness subscales $-18.2(95 \% \mathrm{CI}-24.7$ to -11.7$)$ vs. $-3.6(95 \% \mathrm{CI}-7.8$ to 0.7$)(\mathrm{p}<0.01)$, function subscales $-15.5(95 \% \mathrm{CI}-20.0$ to -11.0$)$ vs. $-2.7(95 \% \mathrm{CI}-5.7$ to 0.3$)(\mathrm{p}<0.01)$, and function score during follow-up $-12.0(95 \% \mathrm{CI}-18.6$ to -5.4$)$ vs. -3.9 $(95 \%$ CI -7.9 to 0.1$)(\mathrm{p}<0.05)$.

Knee function and movement were characterized by changes in flexion angles. In response to treatment, knee flexion improved in both knee in both groups. Improvement of joint function was significantly better in the thermal water-treated group than in the control group: flexion changes were 15.4 (95\% CI 11.7 to 19.1) vs. 6.1 (95\% CI 1.8 to 10.5$)(\mathrm{p}<0.01)$ in the right knee and $11.9(95 \%$ CI 4.7 to 19.2$)$ vs. $3.3(95 \%$ CI 0.7 to 6.0$)(p<0.05)$ in the left knee. Similar results were obtained during the follow-up period: right knee flexion was 14.9 (95\% CI 11.9 to 17.9$)$ vs. 5.9 (95\% CI 2.4 to 9.5) $(\mathrm{p}<0.01)$ and left knee flexion was 14.7 (95\% CI 11.4 to 18.1$)$ vs. $2.8(95 \%$ CI -0.9 to 6.6$)(\mathrm{p}<0.01)$.

As a response to treatment, stair-climb time decreased in both groups; patients completed the unit distance in a shorter period of time. Stair-climb time was slightly more 
decreased in the thermal water-treated group than in the control group when compared to baseline. The difference between the two groups was not significant.

The utility index of the EQ-5D questionnaire showed permanent and significant improvement of general health-related quality of life in the thermal water-treated group compared to the control group after the treatment 0.1606 (95\% CI 0.0975 to 0.2237 ) vs. $0.0634(95 \%$ CI 0.0000 to 0.1268$)(\mathrm{p}<0.05)$ and during the follow-up period $0.1062(95 \%$ CI 0.0328 to 0.1797$)$ vs. $-0.0263(95 \%$ CI -0.1073 to 0.0547$)(\mathrm{p}<0.05)$. The responders' self-rated health measured on the EQ-5D VAS scale slightly improved, but the changes were not statistically significant between the two groups.

\section{DISCUSSION}

In this randomized, controlled, single-blind, follow-up study we evaluated the effectiveness of thermal mineral water on pain, function and quality of life in patients with knee osteoarthritis. The primary endpoint parameters indicating pain at rest and on exertion measured on a visual analogue scale and the secondary endpoint parameters such as the physical function parameter of the WOMAC index, angle of knee flexion, and index values of the EQ-5D global health-associated quality of life questionnaire showed greater improvement and were statistically significant and more durative in the thermal water-treated group compared to the control group. The difference in the above mentioned parameters were significant between the two groups at the end of treatment and during the follow-up period. No adverse reactions were observed during treatment sessions or during the whole study period. The results of our study demonstrated explicitly the effects of thermal mineral water, in the short and long term, compared to the control group who were treated with the tap water. The decrease in pain was not only statistically but also clinically significant. In our own study the VAS scales for the reduction in pain showed a more informative response. The vast majority of studies compared the thermal mineral water treatment for outpatient care with a group not receiving such treatment [132,135,136].

Many Hungarian, Turkish, Israeli authors study compares the treatment of thermal mineral water with tap water treatment. Studies were carried out on treatment with waters of different mineral content. Similar to our results in previous studies comparing the efficacy of balneotherapy applied as a 15 to 18 day course to tap water control in patients with knee 
osteoarthritis $[83,113]$ a significant decrease in pain was observed. Some patients in the group treated with tap water also showed improvements, which confirms the well-known analgesic effect of hot water, but the effect of short-term thermal mineral water proved to be significantly better [137]. This has ratified a systematic review and meta-analysis published by Bender and associates in 2013 which analyzed the pain-reducing effect of balneotherapy. Based on their results, regardless of the composition of the mineral water, balneotherapy significantly decreased joint pain in patients with chronic low back pain and knee and hand osteoarthritis [88].

After the treatment, the WOMAC index parameters of pain, stiffness, physical function and even longterm physical function showed significant clinical improvements. Reduction in pain and improvement in WOMAC scores were most prominent after the treatment course; and at Week 15 this effect already showed a decreasing trend. These results differ from the results of Fioravanti and associates published in 2012, who compared the effects of balneotherapy with routine regular outpatient care and found further reduction in pain, parameters of WOMAC and Lequesne indexes at the 3-month follow-up visit [135].

In contrast, if the thermal mineral water treatment was applied intermittently twice a week for 6 weeks, no significant difference was observed between the treatment group and the tap water-treated control group in pain decrease, improvement in the Lequesne and WOMAC indexes, and improvement in the parameters of the SF-36 questionnaire [136].

Few previous studies have focused on the assessment of changes in the physical state. Our results of knee flexion, showed significant improvement after treatment compared to the control group and during follow-up as well. The stair climb speed improved in both groups, although the change in the thermal mineral water treated group was greater, but no significant difference was observed when comparing the groups. In contrast to our results in a study by Kovacs and Bender it was showed that the stair-climb time improved significantly following 3 week balneotherapy [113].

Only a limited number of studies evaluated the effect of balneotherapy on quality of life. In our study, EQ-5D a self-report questionnaire was evaluated, after the treatment and during the 3-month follow-up period, significant improvement was noted. In other studies, using the SF-36 questionnaire and the Arthritis Impact Measurement Scales a significant 
improvement in quality of life was seen at the end of the treatment course and during the 3month follow-up period [135,136,137].

In studies where balneotherapy was combined with exercise and other treatments [132,138], even in case of severe knee osteoarthritis [139], pain decrease as well as improvement in muscle strength, walking distance, physical function, and quality of life was found to be more significant and longer term. These results were supported by a multicentre study involving a large number of patients [84].

With regard to the common side effects of continuous pharmacological, NSAID therapy, a balneotherapy course can be a useful therapeutic tool or adjunctive therapy in the treatment of knee osteoarthritis.

Our study has some limitations. First, those patients, who bathed in the covered part of the lake, were not allowed to swim, due to the deepness of the water, they had a better opportunity to move around. This might have influenced the improvement in function. Further studies should include larger sample, maybe as a multicenter study. A larger number of patients would have increased the power of the study. Furthermore, patients were not blinded to the received therapy. Bathing in the lake did not make the application of the double-blind method possible. In the future the double-blind method should be used with the tap water control group to ratify the effectiveness of the thermal water treatment. On the other hand patients randomized into the control group were given the opportunity to bathe in the lake for free 15 times after the follow-up visit. This could have led to the results being influenced, however, this contradicts the documented improvement of the control group also. Finally, in a future study it would be useful to design longer follow-up periods and to associate it with a study into its cost-effectiveness. 
Table 9. Measured values, changes from baseline, and statistical data of groups at various time points of the study

\begin{tabular}{|c|c|c|c|c|c|c|c|}
\hline & & \multicolumn{3}{|c|}{ Assessment 2 (3 weeks later) } & \multicolumn{3}{|c|}{ Assessment 3 (15 weeks later) } \\
\hline & & \multicolumn{2}{|c|}{ Changes from baseline } & \multirow{3}{*}{$\begin{array}{c}\text { Group } \\
\text { comparison } \\
\text { Thermal water } \\
- \\
\text { Control }\end{array}$} & \multicolumn{2}{|c|}{ Changes from baseline } & \multirow{2}{*}{$\begin{array}{c}\begin{array}{c}\text { Group } \\
\text { comparison }\end{array} \\
\text { Thermal water }\end{array}$} \\
\hline & & Thermal water & Control & & Thermal water & Control & \\
\hline & & $\begin{array}{l}\text { Mean } \\
95 \% \mathrm{CI}\end{array}$ & $\begin{array}{l}\text { Mean } \\
95 \% \text { CI }\end{array}$ & & $\begin{array}{l}\text { Mean } \\
95 \% \mathrm{CI}\end{array}$ & $\begin{array}{l}\text { Mean } \\
95 \% \text { CI }\end{array}$ & Control \\
\hline $\mathbf{V A}$ & & $\begin{array}{c}\mathbf{- 2 1 . 1} \\
-27.7 \text { to }-14.6\end{array}$ & $\begin{array}{c}\mathbf{- 3 . 7} \\
-9.6 \text { to } 2.2\end{array}$ & $\mathbf{p}<\mathbf{0 . 0 1}$ & $\begin{array}{c}\mathbf{- 1 8 . 8} \\
-26.0 \text { to }-11.5\end{array}$ & $\begin{array}{c}-\mathbf{- 2 . 8} \\
-10.5 \text { to } 5.0\end{array}$ & $\mathbf{p}<\mathbf{0 . 0 1}$ \\
\hline $\mathbf{V A}$ & S II & $\begin{array}{c}\mathbf{- 2 2 . 8} \\
-27.1 \text { to }-18.5\end{array}$ & $\begin{array}{c}-\mathbf{6 . 8} \\
-12.0 \text { to }-1.7\end{array}$ & $\mathbf{p}<0.01$ & $\begin{array}{c}\mathbf{- 1 9 . 0} \\
-25.6 \text { to }-12.4\end{array}$ & $\begin{array}{c}-\mathbf{- 2 . 4} \\
-8.8 \text { to } 4.0\end{array}$ & $\mathbf{p}<0.01$ \\
\hline $\mathbf{V A}$ & S III & $\begin{array}{c}\mathbf{- 2 1 . 7} \\
-27.1 \text { to }-16.3\end{array}$ & $\begin{array}{c}\mathbf{- 8 . 5} \\
-13.1 \text { to }-3.9\end{array}$ & $\mathbf{p}<0.01$ & $\begin{array}{c}\mathbf{- 1 9 . 9} \\
-27.1 \text { to }-12.8\end{array}$ & $\begin{array}{c}-\mathbf{6 . 2} \\
-11.0 \text { to }-1.3\end{array}$ & $\mathbf{p}<0.01$ \\
\hline $\mathbf{V A}$ & S IV & $\begin{aligned} \mathbf{- 1 5 . 1} \\
-18.6 \text { to }-11.5\end{aligned}$ & $\begin{array}{c}\mathbf{- 8 . 0} \\
-11.7 \text { to }-4.3 \\
\end{array}$ & $\mathrm{p}<0.01$ & $\begin{array}{c}\mathbf{- 1 6 . 5} \\
-21.3 \text { to }-11.7\end{array}$ & $\begin{array}{c}\mathbf{- 5 . 6} \\
-9.8 \text { to }-1.3\end{array}$ & $\mathbf{p}<\mathbf{0 . 0 1}$ \\
\hline \multirow{3}{*}{$\sum_{0}^{u}$} & Pain & $\begin{array}{c}\mathbf{- 1 1 . 9} \\
-16.7 \text { to }-7.1\end{array}$ & $\begin{array}{c}\mathbf{- 5 . 5} \\
-9.5 \text { to }-1.6\end{array}$ & $\mathbf{p}<0.05$ & $\begin{array}{c}\mathbf{- 9 . 2} \\
-15.2 \text { to }-3.2\end{array}$ & $\begin{array}{c}\mathbf{- 6 . 8} \\
-10.4 \text { to }-3.1\end{array}$ & NS \\
\hline & Stiffness & $\begin{array}{c}\mathbf{- 1 8 . 2} \\
-24.7 \text { to }-11.7\end{array}$ & $\begin{array}{l}\mathbf{- 3 . 6} \\
-7.8 \text { to } 0.7\end{array}$ & $\mathbf{p}<0.01$ & $\begin{array}{c}\mathbf{- 1 4 . 0} \\
-21.9 \text { to }-6.2\end{array}$ & $\begin{array}{c}-\mathbf{7 . 1} \\
-12.4 \text { to }-1.8\end{array}$ & NS \\
\hline & Function & $\begin{array}{c}-\mathbf{- 1 5 . 5} \\
-20.0 \text { to }-11.0\end{array}$ & $\begin{array}{c}\mathbf{- 2 . 7} \\
-5.7 \text { to } 0.3\end{array}$ & $\mathbf{p}<\mathbf{0 . 0 1}$ & $\begin{array}{c}\mathbf{- 1 2 . 0} \\
-18.6 \text { to }-5.4\end{array}$ & $\begin{array}{c}-\mathbf{- 3 . 9} \\
-7.9 \text { to } 0.1\end{array}$ & $\mathbf{p}<\mathbf{0 . 0 5}$ \\
\hline \multirow{4}{*}{$\stackrel{\Xi}{\Xi}$} & $\begin{array}{l}\text { Flexion } \\
\text { right side }\end{array}$ & $\begin{array}{c}\mathbf{1 5 . 4} \\
11.7 \text { to } 19.1\end{array}$ & $\begin{array}{c}\mathbf{6 . 1} \\
1.8 \text { to } 10.5\end{array}$ & $\mathbf{p}<\mathbf{0 . 0 1}$ & $\begin{array}{c}\mathbf{1 4 . 9} \\
11.9 \text { to } 17.9\end{array}$ & $\begin{array}{c}\mathbf{5 . 9} \\
2.4 \text { to } 9.5\end{array}$ & $\mathbf{p}<\mathbf{0 . 0 1}$ \\
\hline & $\begin{array}{l}\text { Flexion } \\
\text { left side }\end{array}$ & $\begin{array}{c}\mathbf{1 1 . 9} \\
4.7 \text { to } 19.2\end{array}$ & $\begin{array}{c}\mathbf{3 . 3} \\
0.7 \text { to } 6.0\end{array}$ & $\mathbf{p}<0.05$ & $\begin{array}{c}\mathbf{1 4 . 7} \\
11.4 \text { to } 18.1\end{array}$ & $\begin{array}{c}\mathbf{2 . 8} \\
-0.9 \text { to } 6.6\end{array}$ & $\mathbf{p}<0.01$ \\
\hline & $\begin{array}{l}\text { Circumference } \\
\text { right side }\end{array}$ & $\begin{array}{c}\mathbf{- 0 . 3} \\
-0.7 \text { to } 0.1\end{array}$ & $\begin{array}{c}\mathbf{- 0 . 1} \\
-0.3 \text { to } 0.1\end{array}$ & NS & $\begin{array}{c}-\mathbf{- 0 . 4} \\
-0.8 \text { to } 0.0\end{array}$ & $\begin{array}{c}\mathbf{- 0 . 2} \\
-0.7 \text { to } 0.4\end{array}$ & NS \\
\hline & $\begin{array}{l}\text { Circumference } \\
\text { left side }\end{array}$ & $\begin{array}{c}-\mathbf{- 0 . 4} \\
-0.8 \text { to }-0.1\end{array}$ & $\begin{array}{c}\mathbf{- 0 . 1} \\
-0.4 \text { to } 0.2\end{array}$ & NS & $\begin{array}{c}-\mathbf{- 0 . 6} \\
-1.1 \text { to }-0.1\end{array}$ & $\begin{array}{c}\mathbf{0 . 2} \\
-0.4 \text { to } 0.7\end{array}$ & NS \\
\hline \multicolumn{2}{|c|}{ Stair-climb time } & $\begin{array}{c}\mathbf{- 3 . 2} \\
-4.3 \text { to }-2.2\end{array}$ & $\begin{array}{c}\mathbf{- 1 . 6} \\
-3.0 \text { to }-0.3\end{array}$ & NS & $\begin{array}{c}\mathbf{- 1 . 5} \\
-3.1 \text { to } 0.1\end{array}$ & $\begin{array}{c}\mathbf{- 1 . 4} \\
-2.3 \text { to }-0.4\end{array}$ & NS \\
\hline \multicolumn{2}{|c|}{ EQ-5D } & $\begin{array}{c}\mathbf{0 . 1 6 0 6} \\
0.0975 \text { to } 0.2237\end{array}$ & $\begin{array}{c}\mathbf{0 . 0 6 3 4} \\
0.0 \text { to } 0.1268\end{array}$ & $\mathrm{p}<0.05$ & $\begin{array}{c}\mathbf{0 . 1 0 6 2} \\
0.0328 \text { to } 0.1797\end{array}$ & $\begin{array}{c}\mathbf{- 0 . 0 2 6 3} \\
-0.1073 \text { to } 0.0547\end{array}$ & $\mathbf{p}<0.05$ \\
\hline \multicolumn{2}{|c|}{ EQ-5D VAS } & $\begin{array}{c}\mathbf{6 . 1} \\
-1.5 \text { to } 13.6\end{array}$ & $\begin{array}{c}\mathbf{2 . 5} \\
-2.5 \text { to } 7.4\end{array}$ & NS & $\begin{array}{c}\mathbf{5 . 1} \\
-2.1 \text { to } 12.3\end{array}$ & $\begin{array}{c}-\mathbf{- 4 . 4} \\
-10.7 \text { to } 2.0\end{array}$ & NS \\
\hline
\end{tabular}




\section{SUMMARY}

Balneotherapy a medical specialty using the beneficial effects of naturally found mineral waters, gases, and peloids. The most important modalities of use are bathing, drinking and inhalation. The mechanism of action of balneotherapy is not yet completely understood. The physical properties and chemical effects of thermal mineral waters may play a role in their mechanism of action, and the physical effects of buoyancy, hydrostatic pressure and water temperature may be highlighted. Balneotherapeutic procedures are mainly performed in the prevention, treatment, and rehabilitation of musculoskeletal diseases but their use have also been reported in various other indications such as in the treatment or rehabilitation of dermatological, gynaecological, chronic venous insufficiency, chronic occlusive arterial disease, or psychiatric conditions as well as in the rehabilitation of oncology patients. Balneotherapy is usually part of a complex physiotherapeutic treatment. The effectiveness of balneotherapy was long known only empirically. In the past decades, several clinical studies, reviews, and meta-analyses have evaluated the efficacy of balneotherapy mainly in the treatment of musculoskeletal disorders. Balneology is often not recognised as independent medical specialty at a global international and domestic level, because of the lack of scientific evidence, and the fact that balneotherapy is not available in all countries. Low back pain and osteoarthritis are prevalent diseases and their impact is pervasive. The prevalence of these conditions increases markedly with age and they are affected by lifestyle factors, such as obesity and lack of physical activity. They are common cause of severe and chronic pain and physical disability, and they influence the quality of life of affected people. The need for high-quality care for a condition with major personal and societal impact is generally recognised and several guidelines for such care are available. International recommendations for management of musculoskeletal diseases are often divided into three main categories: non-pharmacological, pharmacological and surgical. The efficacy of balneotherapy has been most clearly evidenced in gonarthrosis. Based on systematic review and metaanalysis of randomized controlled trials, recommendations mention balneotherapy as a therapeutic option for knee osteoarthritis. In the recently published Osteoarthritis Research Society International Guidelines for Non-Surgical Management of Knee Osteoarthritis, balneotherapy was considered as an appropriate treatment for specific clinical subphenotypes with multiple joint osteoarthritis and comorbidities. Balneotherapeutic procedures are widely used by physicians and preferred by patients for the treatment of chronic low back pain. Because of the limited scientific evidence balneotherapy is not included in the treatment guidelines for low back 
pain. The first meta-analysis available in English evaluated pooled data from only 5 studies. The first single-blind study was published concomitantly with the above meta-analysis. Evaluating the effectiveness of balneotherapy presents specific methodological issues. In non-pharmacological treatments trials, it is often difficult to perform sham intervention, and blinding of participants is frequently impossible. Moreover, the success of balneotherapy often depends on environmental and other specific factors such as chemical and thermal characteristics, type of bath, nature, and combined intervention. The metaanalysis of completed trials in balneology is challenged by the diversity of their methods, therapies, and outcome parameters. Unlike for drug trials, the lack of adequate funding of balneology research makes it difficult to enroll sufficient numbers of patients in such trials. Metaanalyses and review studies on the efficacy of balneotherapy evaluated the analyzed randomized, controlled trials as of inappropriate methodology. The authors emphasize the need for further additional, confirmatory studies which include an analysis of the person's physical function and their quality of life. Therefore, we aimed to design our studies with appropriate methodology, in accordance with the recommendations for study planning. These trials may provide data for a more precise evaluation of the role of balneotherapy in the management of each condition. I. The aim of the current study was to evaluate the effectiveness of thermal mineral water compared with tap water in the treatment of patients with low back pain, with pain level, mobility and quality of life as primary end-points. Secondary end-points were to record changes in the dose requirements of analgesics and explore the safety profile of treatment. This randomized, doubleblind, controlled, follow-up study included 71 patients who underwent 20-minute daily treatment sessions with medicinal water or with tap water, both at a temperature of $34^{\circ} \mathrm{C}$, on 21 occasions. Both groups underwent additional adjunctive electrotherapy. Outcome measures were visual analogue scale scores, Schober's sign, Domján's signs, Oswestry Disability Index and SF-36 questionnaire. The study parameters were administered at baseline, immediately after treatment, and after 15 weeks. After treatment, there was a significant improvement in all parameters in the thermal water group. This improvement was still evident after 15 weeks. The improvement in the control group was less substantial compared with baseline values. Comparison of the 2 treatments revealed a statistically significant difference in 3 outcome parameters (visual analogue scale scores III, IV and Schober's index). In the subset of patients who completed the study according to the protocol, the greater efficacy of treatment with thermal water was also confirmed by the other study parameters. No adverse reactions were observed during treatment sessions or during 
the whole study period. Potential changes in the efficacy of analgesic therapy could not be monitored, due to the small number of subjects who took analgesics regularly. II. Our primary objective was to evaluate how thermal mineral water therapy influences pain, hand function and quality of life in patients with hand osteoarthritis compared with the control group. The secondary objective of the study was to evaluate whether different water temperatures influence clinical parameters. In this controlled single-blind follow-up study, patients between 50 and 70 years of age with hand osteoarthritis, randomly assigned into three groups. The subjects in the first two groups bathed in thermal mineral water of two different temperatures $\left(36^{\circ} \mathrm{C}\right.$ and $38^{\circ} \mathrm{C}$ ) for three weeks five times a week for 20 minutes a day and received magnetotherapy to their hands three times weekly. The third group received only magnetotherapy. Outcome measures were visual analogue scale scores, handgrip strength, pinchgrip strength, the number of swollen and tender joints of the hand, the duration of morning joint stiffness, HAQ, and SF-36 questionnaire. The study parameters were administered at baseline, immediately after treatment and after 13 weeks. The study included 63 patients. Statistically significant improvement was observed in several studied parameters after the treatment and during the follow-up study in the thermal water groups versus the control group. The $38^{\circ} \mathrm{C}$ thermal water treatment significantly improved the pinch strength of the right hand and the HAQ parameters even in the long term. III. The primary endpoint of the study was the evaluation and documenting of the pain-reducing effect of Lake Hévíz thermal mineral water on knee pain at rest or on exertion in patients with mild to moderate knee osteoarthritis as well as the assessment of the therapeutic effect compared to the control group treated with warmed tap water. The secondary endpoints included the evaluation of the effect of Lake Hévíz thermal mineral water on knee function and quality of life. In this single-blind, follow-up study included 77 outpatients between 45 and 75 years of age with mild to moderate osteoarthritis of the knee meeting the American College of Rheumatology classification criteria. Patients were randomized into two groups. In group I, subjects bathed in Lake Hévíz and in group II, patients were treated in a pool full of tap water. Water temperature was $34^{\circ} \mathrm{C}$ for both groups. Participants underwent 30-minute therapy sessions, five times a week for three weeks. Outcome measures were pain visual analogue scale scores, active flexion degree, knee circumference, stair-climb time, WOMAC and EQ-5D. Study parameters were recorded at baseline, immediately after treatment, and after 15 weeks. Comparison of the two groups revealed a statistically significant difference in pain visual analogue scale scores, active flexion degree, physical function components of WOMAC, and EQ-5D scores even after 15 weeks. 


\section{CONCLUSIONS AND NEW RESULTS}

I. Our randomized, tap water-controlled, follow-up study is the first double-blind investigation in the English literature evaluating the efficacy of balneotherapy in patients with chronic low back pain. Our results suggest that treatment with thermal mineral waters is an effective treatment modality for the management of chronic lumbar pain, besides improves the function and quality of life. In view of the differences between the groups treated with thermal versus tap water, balneotherapy with the former may be regarded as a more effective basic treatment modality, as well as an efficient adjunct to pharmaco- and physical therapy, owing to the addition and enhancement of positive effects.

II. Our randomized, controlled, single-blind, follow-up study is the first trial in the English literature evaluating the effect of balneotherapy in hand osteoarthritis. Based on the results thermal water treatment was more effective, clinically significant improvement was recorded in pain reduction and hand function, and and quality of life compared with the control magnetotherapy group. These benefits were maintained at 13 weeks. The $38^{\circ} \mathrm{C}$ thermal water treatment significantly improved the function compared with control, even in the long term. Based on our results, we can conclude that the balneotherapy is a possible therapeutic option in the treatment of hand osteoarthritis.

III. Our randomized, tap water-controlled, single-blind study confirmed the findings of previous studies on the efficacy of balneotherapy in the treatment of patients with knee osteoarthritis. Our results showed significant improvement in knee pain reduction, knee function, and quality of life and these changes were measurable even 12 weeks after the treatment. The difference, were significant between the two groups at the end of treatment and during the follow-up period. With regard to the common side effects of continuous pharmacological, NSAID therapy, balneotherapy can be a useful therapeutic tool or adjunctive therapy in the treatment of knee osteoarthritis. 


\section{ACKNOLEDGEMENTS}

I owe a debt of gratitude to my doctoral advisor, Tamás Bender, M.D., Ph.D., D.Sc., for his continuing and magnanimous support from the beginning of our acquaintance through my years in the Doctoral School.

My sincere thanks also goes to László Szekeres, M.D., who fundamentally oriented and helped me to become a rheumatologist as well as encouraged my interest in balneology.

Special thanks to András Németh, MD., for his outstanding knowledge in statistics and his dedicated work in preparation of the manuscripts.

My sincerest thanks to László Czirják, M.D., Ph.D., D.Sc., for his teachings.

I am also grateful to Alice Dalmadi, M.D., for our first balneological examination.

I am also thankful to Katalin Horváth, M.D., for the good atmosphere for our common work.

I would like to thank Kránicz Ágota, M.D., for extending her support and professional assistance in our everyday work.

Thank you to the management of the St. András Hospital, Hévíz and to Zsuzsanna Mándó, M.D., for supporting and helping my work.

My special thanks go to the staff of the „G” and „D” Department for our daily common work.

With much fondness I thank my mother for her encouragement and background work that she does till date so she can support me. To my husband, my children, my family members, a special thank you for your patience, love and endurance, which made it possible for me to carry out my work. 


\section{REFERENCES}

1. Csermely M: A fizioterápia kézikönyve, White Golden Book, Budapest, 2004.

2. Gyarmati N, Kulisch Á, Mándó Zs. A balneológia helye az egészségturizmusban. In: Lőke Zs., szerk. Desztinációmenedzsment az egészségturizmusban. Keszthely, Pannon Egyetem Georgikon Kar, Keszthely 2014: 77-107.

3. Géher P, Kovács Cs, Nagy K. A gyógyvizek felosztása, élettani hatásaik. In: Bender T, ed. Balneoterápia és hidroterápia. Budapest: Medicina Könyvkiadó Zrt; 2014: 33-47.

4. Bender T, Karagülle Z, Bálint GP, Gutenbrunner C, Bálint PV, Sukenik S. Hydrotherapy, balneotherapy, and spa treatment in pain management. Rheumatol Int 2005; 25: 220-224.

5. Gutenbrunner C, Bender T, Cantista $\mathrm{P}$ and Karagülle Z. A proposal for a worldwide definition of health resort medicine, balneology, medical hydrology and climatology. Int J Biometeorol 2010; 54: 495-507.

6. Bender T: A balneoterápia és hidroterápia hatása mozgásszervi megbetegedésekben. LAM 2005; 15(12): 921-926.

7.van Tubergen A, van der Linden S. A brief history of spa therapy.

Ann Rheum Dis 2002; 61: 273-275.

8. Bender T, Balint PV, Balint GP. A brief history of spa therapy.

Ann Rheum Dis 2002; 61: 949.

9. Bender T. A balneoterápia és a hidroterápia fogalma. In: Bender T, ed. Balneoterápia és hidroterápia. Budapest: Medicina Könyvkiadó Zrt; 2014: 9-10.

10. Bender T. A balneoterápia klinikuma. In: Bender T, ed. Balneoterápia és hidroterápia. Budapest: Medicina Könyvkiadó Zrt; 2014: 53-54. 
11. Costantino M, Filippelli A. Impact of SPA therapy with sulphureous mineral water on quality of life and psychological distress in chronic plaque psoriasis. Clin Ter 2014165 (4): 277-84.

12. Brockow T' Schiener R, Franke A, Resch KL, Peter RU. A pragmatic randomized controlled trial on the effectiveness of highly concentrated saline spa water baths followed by UVB compared to UVB only in moderate to severe psoriasis.

J Altern Complement Med. 2007 Sep; 13 (7): 725-32.

13. Adler-Cohen C, Czarnowicki T, Dreiher J, Ruzicka T, Ingber A, Harari M. Climatotherapy at the Dead Sea: an effective treatment modality for atopic dermatitis with significant positive impact on quality of life. Dermatitis. 2012 Mar-Apr; 23 (2): 75-80.

14. Zámbó L, Dékány M, Bender T. The efficacy of alum-containing ferrous thermal water in the management of chronic inflammatory gynaecological disorders-a randomized controlled study. Eur J Obstet Gynecol Reprod Biol. 2008 Oct; 140 (2): 252-7.

15. Forestier RJ, Briancon G, Francon A, Erol FB, Mollard JM. Balneohydrotherapy in the treatment of chronic venous insufficiency. Vasa. 2014 Sep; 43 (5): 365-71.

16. Carpentier PH, Blaise S, Satger B, Genty C, Rolland C, Roques C, Bosson JL. A multicenter randomised controlled trial evaluating balneoherapy in patients with advanced chronic venous insufficiency. J Vasc Surg. 2014 Feb;59 (2): 447-454.

17. Fabry R, Monnet P, Schmidt J, Lusson JR, Carpentier PH, Baguet JC, Dubray C. Clinical and microcirculatory effects of transcutaneous $\mathrm{CO} 2$ therapy in intermittent claudication. Randomized double-blind clinical trial with a parallel design. Vasa. 2009 Aug; 38 (3): 21324.

18. Dubois O, Salamon R, Germain C, Poirier MF, Vaugeois C, Banwarth B, Mouaffak F, Galinowski A, Olié JP. Balneotherapy versus paroxetine in the treatment of generalized anxiety disorder. Complement Ther Med. 2010 Feb; 18 (1): 1-7. 
19. Mourgues C, Gerbaud L, Leger S, Auclair C, Peyrol F, Blanquet M, Kwiatkowski F, Leger-Enreille A, Bignon YJ. Positive and cost-effectiveness effect of spa therapy on the resumption of occupational and non-occupational activities in women in breast cancer remission: a French multicentre randomised controlled trial.

Eur J Oncol Nurs. 2014 Oct; 18 (5): 505-11.

20. Ponyi J. Studies of the Crustacea fauna of a Hungarian hot spring (Hévíz Spa). Zool Ib Syst 1992; 119: 397-404.

21. Gyarmati N, Kulisch A. History and description of Hévíz spa with special emphasis on weigth bath, Press. Therm. Climat. 2008; 145: 233-242.

22. Moll K. A discusherniák gyógykezelése az ún. "súlyfürdővel”. Orvosi Hetilap 1953; 94: 292-296.

23. Sukenik S, Flusser D, Abu-Shakra M. The role of SPA therapy in various rheumatic diseases. Rheum Dis North Am 1999, 25: 883-897.

24. Fioravanti A, Cantarini L, Guidelli GM, Galeazzi M. Mechanisms of action of spa therapies in rheumatic diseases: what scientific evidence is there? Review. Rheumatol Int 2011; 31: 1-8.

25. Varga Cs. Volatile organics in thermal spa waters: active ingredients or environmental toxicants? Thermae \& Spa Medicine March 2012 Vol. 2, Nº1.

26. Bender T. A balneoterápia és a hidroterápia fogalma. In: Bender T, ed. Balneoterápia hatásmechanizmusa. Budapest: Medicina Könyvkiadó Zrt; 2014: 27-32.

27. Arborelius M, Ballidin U, Lilja B, Lungren C. Haemodynamic changes in man during immersion with head above water. AerospaceMedicine 1972; 43: 592-8. 
28. Hildebrand K, Barbosa-Leiker C, Melchior D. Different Immersion Temperatures' Impact Upon Blood Pressure of Individuals With Varied Sex and Age. International Journal of Aquatic Research and Education, 2012, 6, 303-314.

29. Begin R, Epstein M, Sackner M, Levinson R, Dougherty R, Duncan D. Effects of water immersion to the neck on pulmonary circulation and tissue volume in man. J Appl Physiol 1976; 40: 293-9.

30. Epstein M. Renal effects of head-out water immersion in man: implications for an understanding of volume homeostasis. Physiol Rev 1978; 58: 529-81.

31. Epstein M, Pins D, Miller M. Suppression of ADH during water immersion in normal man. J ApplPhysiwl 1975; 38: 1038-44.

32. Epstein M. Renal effects of head-out water immersion in humans: a 15 year update. Physiol Rev 1992; 72: 563-621.

33. O’Hare JP, Heywood A, Summerhayes C, Lunn G, Evans JM, Walters G, Corrall RJ, Dieppe PA. Observations on the effect of immersion in Bath spa water.

Brit Med J (Clin Res Ed) 1985; 291: 1747-51.

34. Becker BE. Biophysiologic aspects of hydrotherapy. In Becker BE, Cole AJ. Comprehensive aquatic therapy. 1997 First edn. Butterworth-Heinemann, Boston, pp 17-48.

35. Kjelllgren A, Sundequist U, Norlander T, Archer T. Effects of flotation-REST on muscle tension pain. Pain Res Manag 2001; 6: 181-189.

36. Becker BE. Aquatic therapy: scientific foundations and clinical rehabilitation applications. PM R 2009; 1: 859-72.

37. Melzack R, Wall PD. Pain mechanism: a new theory. Science 1965, 150: 971-979. 
38. Kuczera M, Kokot F. The influence of SPA therapy on endocrine system. Stress reaction hormones. Pol Arch Med Wewn 1996, 95: 11-20.

39. Bender T, Nagy G, Barna I, Tefner I, Kádas E, Géher P. The effect of physical therapy on beta-endorphin levels. Eur J Appl Physiol 2007; 100: 371-82.

40. Becker EB, Hildenbrand K, Whitcomb RK, Sanders JP. Biophysiologic effects of warm water immersion. Int J of Aquat Res Educ 2009; 3: 24-37.

41. Sukenik S, Flusser D, Abu-Shakra M The role of spa therapy in various rheumatic diseases. Rheum Dis Clin North Am 1999; 25: 883-97

42. Hall J, Skevington SM, Maddis PJ, Chapman K. A randomized and controlled trial of hydrotherapy in rheumatoid arthritis. Arthritis Care Res 1996; 9: 206-215.

43. Shani J, Barak S, Levi D, Ram M, Schachner ER, Schlesinger T et al. Skin penetration of minerals in psoriatics and guinea pigs bathing in hypertonic salt solutions. Pharmacol Res 1985, 17: 501-506.

44. Hildebrandt G, Gutenbrunner C. Balneologie. In: Hildebrandt G, Gutenbrunner C, editors. Handbuch der Balneologie und Medizinischen Klimatologie. Berlin, Heidelberg: Springer; 1998. p. 271-3.

45. Nagy K, Clinical and experimental tests carried out with medicinal water and medicinal caves containing radon University Doctoral Thesis 2008, University of Szeged Clinical Medicine Doctoral School.

46. Pozsgai G, Benkő R, Barthó•L, Horváth K, Pintér E. Thermal spring water drinking attenuates dextran-sulfate-sodium-induced colitis in mice.

Inflammopharmacol 2015, Feb; 23 (1): 57-64. 
47. Boros M, Kemény Á, Sebők B, Bagoly T, Perkecz A, Petőházi Z, Maász G, Schmidt J, Márk L, László T, Helyes ZS, Szolcsányi J, Pintér E Sulphurous medicinal waters increase somatostatin release: it is a possible mechanism of antiinflammatory effect of balneotherapy in psoriasis. Eur J of Integr Med 2013, 5: 109118.

48. Markovic M, Majkic-Singh N, Ignjatovic S. Beneficial effects of cellular stress response in traditional spa treatment of rheumatoid arthritis. Clin Lab. 2009; 55: 235-41.

49. Tarner IH, Müller-Ladner U, Uhlemann C, Lange U The effect of mild whole-body hyperthermia on systemic levels of TNF-alpha, IL-1 beta, and IL-6 in patients with ankylosing spondylitis. Clin Rheumatol 2009, 28: 397-402.

50. Shehata M, Schwarzmeier JD, Hilgarth M, Demirtas D, Richter D, Hubmann R, Boeck P, Leiner G, Falkenbach A. Effect of combined spa-exercise therapy on circulating TGF-beta1 levels in patients with ankylosing spondylitis.

Wien Klin Wochenschr. 2006 May; 118 (9-10): 266-72.

51. Ardic F, Ozgen M, Aybek H, Rota S, Cubukc G, Gökgöz A. Effect of balneotherapy on serum IL-1, PGE2 and LTB4 levels in fibromyalgia patients. Rheumatol Int 2007, 27: 441-446.

52. Sieghart D, Liszt M, d, Wanivenhaus A, Bröll H, Kiener H, Klösch B, Steiner G. Hydrogen sulphide decreases IL-1b-induced activation of fibroblast-like synoviocytes from patients with osteoarthritis. J. Cell. Mol. Med. Vol 19, No1, 2015 pp. 187-197.

53. Bellometti S, Cecchettin M, Galzigna L. Mud-pack therapy in osteoarthrosis changes levels of chondrocytes markers. Clin Chim Acta 1997, 268: 101-106.

54. Fioravanti A, Cantarini L, Bacarelli MR, Lalla A, Ceccatelli L. Effects of Spa therapy on serum leptin and adiponectin levels in patients with knee osteoarthritis.

Rheumatology International, 2010, 31 (7), pp. 879-882. 
55. Ekmekcioglu C, Strauss-Blasche G, Holzer F, Marktl W. Effect of sulfur baths on antioxidative defense systems, peroxide concentrations and lipid levels in patients with degenerative osteoarthritis. Forsch Komplementmed Klass Natheilkd 2002; 9(4):216- 20.

56. Leibetseder V, Strauss-Blasche G, Holzer F, Marktl W, Ekmercioglu C. Improving homocysteine levels through balneotherapy: effects of sulphur baths.

Clin Chim Acta 2004, 343: 105-111.

57. Bender T, Bariska J, Vághy R, Gomez R, Kovács I. Effect of balneotherapy on the antioxidant system—a controlled pilot study. Arch Med Res. 2007, 38: 86-89.

58. Chou R, Qaseem A, Snow V, Casey D, Cross JT Jr, Shekelle P, et al. Diagnosis and treatment of low back pain: a joint clinical practice guideline from the American College of Physicians and the American Pain Society. Ann Intern Med. 2007; 147 (7): 478-91.

59. Rannou F, Poiraudeau S. Henrotin Y. Low back pain includin sciatica and DISH In: Bijlsma JWJ ed. EULAR Compendium on Rheumatic Diseases 2009 BMJ Publishing Group 477-492.

60. Henschke N, Maher CG, Refshauge KM, et al. Prognosis in patients with recent onset low back pain in Australian primary care: inception cohort study. BMJ 2008; 337: a171.

61. Hancock MJ, Maher CG, Latimer J, et al. Can rate of recovery be predicted in patients with acute low back pain? Development of a clinical prediction rule. Eur J Pain 2009; 13: 51-5.

62. Chou R, Qaseem A, Snow V, Casey D, Cross JT Jr, Shekelle P, Owens DK. Clinical Efficacy Assessment Subcommittee of the American College of Physicians; American College of Physicians; American Pain Society Low Back Pain Guidelines Panel. Diagnosis and treatment of low back pain: a joint clinical practice guideline from the American College of Physicians and the American Pain Society. Ann Intern Med. 2007 Oct 2; 147(7): 478-91. 
63. Valero R, Varela E, Küçükdeveci AA, Oral A, Ilieva E, Berteanu M, Christodoulou N. Spinal pain management. The role of physical and rehabilitation medicine physicians. The European perspective based on the best evidence. A paper by the UEMS-PRM Section Professional Practice Committee. Eur J Phys Rehabil Med. 2013 Oct; 49 (5): 715-25.

64. Ladeira CE, Evidance based practice guidlines for management of low back pain: physical therapy implications Rev Bras Fisioter. 2011 May-Jun, 15(3): 190-9.

65.Woolf A, Pfleger B. Burden of major musculoskeletal conditions. Bull World Health Organ 2003; 81 (9): 646-56.

66. Murray CJL, Lopez AD, editors. The global burden of disease. A comprehensive assessment of mortality and disability from diseases, injuries, and risk factors in 1990 and projected to 2020. Cambridge (MA): Harvard School of Public Health on behalf of the World Health Organization and The World Bank; 1996.

67. Pereira D, Peleteiro B, Araujo J, Branco J, Santos RA, Ramos E. The effect of osteoarthritis definition on prevalence and incidence estimates: a systematic review. Osteoarthr Cartil 2011, 19: 1270-1285.

68. Van der Pas et al. European project on osteoarthritis: design of a six-cohort study on the personal and societal burden of osteoarthritis in an older European population. BMC Musculoskeletal Disorders 2013, 14: 138.

69. Sellam J, Herrero-Beaumont G, Berenbaum F. Osteoarthritis: pathogenesis, clinical aspects and diagnosis. In: Bijlsma JWJ ed. EULAR Compendium on Rheumatic Diseases 2009 BMJ Publishing Group 444-463.

70. Zhang W, Doherty M, Leeb BF, et al. ESCISIT. EULAR evidence-based recommendations for the diagnosis of hand osteoarthritis: report of a task force of ESCISIT. Ann Rheum Dis 2009; 68: 8-17. 
71. Altman R, Alarco $\mathrm{n} \mathrm{G}$, Appelrouth D, et al. The American College of Rheumatology criteria for the classification and reporting of osteoarthritis of the hand. Arthritis Rheum 1990; 33: 1601-1610.

72. Altman R, Asch E, Bloch D, Bole G, Borenstein D, Brandt K, Christy W, Cooke TD, Greenwald R, Hochberg $M$ et al. Development of criteria for the classification and reporting of osteoarthritis. Classification of osteoarthritis of the knee. Diagnostic and Therapeutic Criteria Committee of the American Rheumatism Association. Arthritis Rheum 1986; 29: 1039-1049.

73. Jordan KM, Arden NK, Doherty M, Bannwarth B, Bijlsma JW et al. EULAR. Recommendations 2003: an evidence based approach to the management of knee osteoarthritis: Report of Task Force of the Standing Committee for International Clinical Studies Including Therapeutic Trials (ESCISIT). Ann Rheum Dis 2003; 62: 1145-1155.

74. Zhang W, Doherty M, Leeb BF, et al. EULAR evidence based recommendations for the management of hand osteoarthritis: report of a Task Force of the EULAR Standing Committee for International Clinical Studies Including Therapeutics (ESCISIT). Ann Rheum Dis 2007; 66: 377-388.

75. Fernandes L, Hagen KB, Bijlsma JWJ, Andreassen O, Christensen P, Conaghan PG et al. EULAR recommendations for the non-pharmacological core management of hip and knee osteoarthritis. Ann Rheum Dis 2013; 72: 1125-35.

76. Hochberg MC, Altman RD, April KT, Benkhalti M, Guyatt G, McGowan J, Towheed T, Welch V, Wells G, Tugwell P. American College of Rheumatology. American College of Rheumatology 2012 recommendations for the use of nonpharmacologic and pharmacologic therapies in osteoarthritis of the hand, hip, and knee. Arthritis Care Res (Hoboken). 2012 Apr; 64 (4): 465-74.

77. Larmer PJ, Ready ND, Aubert ER, Kersten P. Systematic review of guidelines for the physical management of osteoarthritis. Arch Phys Med Rehabil. 2014 Feb; 95 (2): 375-89. 
78. McAlindon TE, Bannuru RR, Sullivan MC, Arden NK, Berenbaum F, Bierma-Zeinstra SM, Hawker GA et al. OARSI guidelines for the non-surgical management of knee osteoarthritis. Osteoarthritis Cartilage. 2014 Mar; 22 (3): 363-88.

79. Docherty M, Yazdani R, Punzi L. Management of osteoarthritis. In: Bijlsma JWJ ed. EULAR Compendium on Rheumatic Diseases 2009 BMJ Publishing Group 464-476.

80. Kamioka H, Tsutani K, Maeda M, Hayasaka S, Okuizum H, Goto Y, Okada S' Kitayuguchi J, Abe T. Assessing the quality of study reports on spa therapy based on randomized controlled trials by the spa therapy checklist (SPAC). Complement Ther Clin Pract. 2014 Nov; 20 (4): 317-33.

81. Pittler MH, Karagulle MZ, Karagulle M, Ernst E. Spa therapy and balneotherapy for treating low pain: meta-analysis of randomized trials. Rheumatology 2006; 45: 880-884.

82. Karagülle M, Karagülle MZ. Effectiveness of balneotherapy and spa therapy for the treatment of chronic low back pain: a review on latest evidence. Clin Rheumatol. 2015 Feb; 34 (2): 207-14.

83. Szücs L, Ratkó I, Leskó T, Szoor I, Genti G, Bálint G. Double-blind trial on the effectiveness of the Puspokladany thermal water on arthrosis of the knee-joints. J R Soc Health 1989; 109: 7-9.

84. Forestier R, Desfour H, Tessier JM, Françon A, Foote AM, Genty C, Rolland C, Roques CF, Bosson JL. Spa therapy in the treatment of knee osteoarthritis: a large randomised multicentre trial. Ann Rheum Dis 2010; 69: 660-5.

85. Verhagen A, Bierma-Zeinstra S, Lambeck J, Cardoso JR, de Bie R, Boers M, de Vet HC. Balneotherapy for osteoarthritis. A cochrane review. J Rheumatol 2008; 35: 1118-23. 
86. Falagas ME, Zarkadoulia E, Rafailidis PI. The therapeutic effect of balneotherapy: evaluation of the evidence from randomised controlled trials. Int J Clin Pract 2009; 63: 1068-84.

87. Harzy T, Ghani N, Akasbi N, Bono W, Nejjari C. Short- and long term therapeutic effects of thermal mineral waters in knee osteoarthritis: a systematic review of randomized controlled trials. Clin Rheumatol 2009; 28: 501-507.

88. Bender T, Bálint G, Prohászka Z, Géher P, Tefner IK. Evidence-based hydro- and balneotherapy in Hungary - a systematic review and meta-analysis. Int J Biometeorol 2013; 58: 311-323.

89. Tubach F, Ravaud P, Baron G, et al. Evaluation of clinically relevant changes in patient reported outcomes in knee and hip osteoarthritis: the minimal clinically important improvement. Ann Rheum Dis. 2005; 64 (1): 29-33.

90. Hägg O, Fritzell P, Nordwall A; Swedish Lumbar Spine Study Group. The clinical importance of changes in outcome scores after treatment for chronic low back pain. Eur Spine J. 2003 Feb; 12 (1): 12-20.

91. Bellamy N, Buchanan WW, Goldsmith CH, Campbell J, Stitt LW. Validation study of WOMAC: a health status instrument for measuring clinically important patient relevant outcomes to antirheumatic drug therapy in patients with osteoarthritis of the hip or knee. J Rheumatol 1988; 15: 1833-40.

92. Davies GM, Watson DJ, Bellamy N. Comparison of the responsiveness and relative effect size of the Western Ontario and McMaster Universities Osteoarthritis Index and the ShortForm Medical Outcomes Study Survey in a randomized clinical trial of osteoarthritis patients. Arthritis Care Res. 1999; 12: 172-179.

93. Allyson JC, Voaklander DC, Johnston DWC, Suarez-Almazor M. The effect of age on pain, function, and quality of life after total hip and knee arthroplasty. Arch Intern Med. 2001; 161: 454-460. 
94. Péntek M, Genti Gy, Pintye A, Ratkó I. A WOMAC VA3.0 index magyar verziójának vizsgálata térd-és csípőarthrosisos betegeken. Magyar Reumatológia 1999; 40: 94-97.

95. Bruce B, Fries J.F. The Health Assessment Questionnaire (HAQ).

Clin Exp Rheumatol 2005; 23 (Suppl. 39): S14-S18.

96. Bruce B, Fries J.F. The Stanford health assessment questionnaire (HAQ): a review of its history, issues, progress, and documentation. J Rheumatol 2003; 30: 167-78.

97. Bruce B, Fries J.F. Longitudinal comparison of the Health Assessment Questionnaire (HAQ) and the Western Ontario and McMaster Universities Osteoarthritis Index (WOMAC). Arthritis Rheum (Arthritis Care Res) 2004; 51: 730-7.

98. Rojkovich B, Poór Gy, Korda J. Az EULAR által rheumatoid arthritisben javasolt ízületi index reprodukálhatóságának multicentrikus vizsgálata. Magy Reumatol 1997; 38: 206-212.

99. Fairbank JCT, Pynsent PB. The Oswestry Disability Index. Spine 2000; 25 (22): 2940-2953

100. Ormos G, Szabó Cs, Korányi Á, Csiki J. Betegség-specifikus funkciócsökkenési indexek hazai validálása. Rehabilitációs Társaság Vándorgyülése, Sopron, 2003.

101. www.sf-36.org

102. Czimbalmos Á, Nagy Zs, Varga Z, Husztik P. Páciens megelégedettség vizsgálat SF-36 kérdőívvel, a magyarországi normálértékek meghatározása. Népegészségügy 1999; 80: 4-19.

103. www.euroqol.org

104. Guillemin F, Constant F, Collin JF, Boulange M. Short and longterm effect of spa therapy in chronic low back pain. Br J Rheumatol 1994; 33: 148-151. 
105. Constant F, Collin JF, Guillemin F, Boulange M. Effectiveness of spa therapy in chronic low back pain: a randomized clinical trial. J Rheumatol 1995; 22: 1315-1320.

106. Constant F, Guillemin F, Collin JF, Boulange M. Use of spa therapy to improve the quality of life of chronic low back pain patients. Med Care 1998; 36: 1309-1314.

107. Konrad K, Tatrai T, Hunka A, Vereckei E, Korondi I. Controlled trial of balneotherapy in treatment of low back pain. Ann Rheum Dis 1992; 51: 820-822.

108. Yurtkuran M, Kahmraman Z, Sivrioglu K, Afsin Y, Dogan M. Balneotherapy in low back pain. Eur J Phys Med Rehabil 1997; 7: 120-123.

109. Balogh Z, Ördögh J, Gász A, Német L, Bender T. Effectiveness of balneotherapy in chronic low back pain - a randomized singleblind controlled follow-up study. Forsch Komplementarmed und Klass Naturheilkd 2005; 12: 196-201.

110. Domján L, Nemes T, Bálint GP, Tóth Z, Gömör B. A simple method for measuring lateral flexion of the dorsolumbar spine. J Rheumatol 1990; 17: 663-665.

111. Franke A, Reiner L, Pratzel HG, Franke T, Resch KL. Longterm efficacy of radon spa therapy in rheumatoid arthritis - a randomized, sham-controlled study and follow-up. Rheumatology 2000; 39: 894-902.

112. van Tubergen A, Landewe R, van der Heijde D, Hidding A, Wolter N, Asscher M, et al. Combined spa therapy is effective in patients with ankylosing spondylitis: a randomized controlled trial. Arthritis Care Res 2001; 45: 430-438.

113. Kovács I, Bender T. The therapeutic effects of Cserkeszolo thermal water in osteoarthritis of the knee: a double blind, controlled, follow- up study.

Rheumatol Int 2002; 21: 218-221. 
114. Balint GP, Buchanan WW, Adam A, Ratko I, Poor L, Balint PV, et al. The effect of the thermal mineral water of Nagybaracska on patients with knee joint osteoarthritis - a double blind study. Clin Rheumatol 2007; 26: 890-894.

115. Donmez A, Karagulle MZ, Tercan N, Dinler M, Issever H, Karagulle M, et al. SPA therapy in fibromyalgia: a randomised controlled clinic study. Rheumatol Int 2005; 26: 168-172.

116. Deyo RA, Rattie M, Beurskens AJ, Bombardier C, Croft P, Koes B, et al. Outcome measures for low back pain research. A proposal for standardized use. Spine 1998; 23: 2003-2013.

117. Weigl M, Ewert T, Kleinschmidt J, Stucki G. Measuring the outcome of health resort programs. J Rheumatol 2006; 33: 764-770.

118. Hamalainen O, Kemppainen P. Experimentally induced ischemic pain and so-called diaphase fix current. Scand J Rehabil Med 1990; 22: 25-27.

119. Kulisch Á, Dalmadi A, Mózes M, Kertai S, Végh Gy, Haraszti L, Vathy Á, Czimbalmos Á. The therapeutics effects of Hévíz thermal water in osteoporosis and LBP (oral presentation) 35 th World Congress of ISMH Istanbul 2006.

120. Tefner IK, Németh A, Lászlófi A, Kis T, Gyetvai G, Bender T. The effect of spa therapy in chronic low back pain: a randomized controlled, single-blind, follow-up study. Rheumatol Int 2012; 32: 3163-3169.

121. Kesiktas N, Karakas S, Gun K, Gun N, Murat S, Uludag M. Balneotherapy for chronic low back pain: a randomized, controlled study. Rheumatol Int 2012; 32: 3193-3199.

122. Gremeaux V, Benaïm C, Poiraudeau S, Hérisson C, Dupeyron A, Coudeyre E. Evaluation of the benefits of low back pain patients' education workshops during spa therapy. Joint Bone Spine 2013; 80: 82-87. 
123. Maheu E, Altman RD, Bloch DA, et al. Osteoarthritis Research Society International Hand OA Task Force. Design and conduct of clinical trials in patients with osteoarthritis of the hand: recommendations from a task force of the Osteoarthritis Research Society International. OsteoArthritis Cartilage 2006; 14: 303-322.

124. Altman R, Alarco' n G, Appelrouth D. The American College of Rheumatology criteria for the classification and reporting of osteoarthritis of the hand. Arthritis Rheum 1990; 33: 1601-1610.

125. Günther CM, Bürger A, Rickert M, Crispin A and Schulz CU. Grip strength in healthy caucasian adults: reference values. J Hand Surg Am 2008; 33: 558-565.

126. Codish S, Abu-Shakra M, Flusser D, Friger M and Sukenik S. Mud compress therapy for the hands of patients with rheumatoid arthritis. Rheumatol Int 2005; 25: 49-54.

127. Breger Stanton DE, Lazaro R, Macdermid JC. A systematic review of the effectiveness of contrast baths. J Hand Ther 2009; 22: 57-69.

128. Nicolakis P, Kollmitzer J, Crevenna R, Bittner C, Erdogmus CB, Nicolakis J. Pulsed magnetic field therapy for osteoarthritis of the knee-a double-blind sham-controlled trial. Wien Klin Wochenschr 2002; 114: 678-684.

129. Ganesan K, Gengadharan AC, Balachandran C, Manohar BM and Puvanakrishnan R. Low frequency pulsed electromagnetic field-a viable alternative therapy for arthritis. Indian J Exp Biol 2009; 47: 939-948.

130. Vavken P, Arrich F, Schuhfried O and Dorotka R. Effectiveness of pulsed electromagnetic field therapy in the management of osteoarthritis of the knee: a metaanalysis of randomized controlled trials. J Rehabil Med 2009; 41: 406-411.

131. Fioravanti A, Valenti M, Altobelli E. Clinical efficacy and cost-effectiveness evidence of spa therapy in osteoarthritis. The results of 'Naiade' Italian Project. Panminerva Med 2003; 45: 211-217. 
132. Fioravanti A, Iacoponi F, Bellisai B, Cantarini L, Galeazzi M. Short- and long-term effects of spa therapy in knee osteoarthritis. Am J Phys Med Rehabil 2010; 89: 125-32.

133. Yurtkuran M, Yurtkuran M, Alp A, Nasircilar A, Bingöl U, Altan L et al. Balneotherapy and tap water therapy in the treatment of knee osteoarthritis. Rheumatol Int 2006; 27: 19-27.

134. Altman R, Asch E, Bloch D, Bole G, Borenstein D, Brandt K, Christy W, Cooke TD, Greenwald R, Hochberg $M$ et al. Development of criteria for the classification and reporting of osteoarthritis. Classification of osteoarthritis of the knee.

Diagnostic and Therapeutic Criteria Committee of the American Rheumatism Association. Arthritis Rheum 1986; 29: 1039-1049.

135. Fioravanti A, Giannitti C, Bellisai B, Iacoponi F, Galeazzi M. Efficacy of balneotherapy on pain, function and quality of life in patients with osteoarthritis of the knee. Int J Biometeorol 2012; 56: 583-90.

136. Sherman G, Zeller L, Avriel A, Friger M, Harari M, Sukenik S. Intermittent balneotherapy at the Dead Sea area for patients with knee osteoarthritis. Isr Med Assoc J. 2009; 11 (2): 88-93.

137. Gaal J, Varga J, Szekanecz Z, Kurkó J, Ficzere A, Bodolay E, Bender T. Balneotherapy in elderly patients: effect on pain from degenerative knee and spine conditions and on quality of life. Isr Med Assoc J 2008; 10: 365-369.

138. Yurtkuran M, Yurtkuran M, Alp A, Nasircilar A, Bingöl U, Altan L, Sarpdere G. Balneotherapy and tap water therapy in the treatment of knee osteoarthritis. Rheumatol Int. 2006; 27 (1): 19-27.

139. Karagülle M, Karagülle MZ, Karagülle O, Dönmez A, Turan M. A 10-day course of SPA therapy is beneficial for people with severe knee osteoarthritis. A 24-week randomised, controlled pilot study. Clin Rheumatol. 2007, 12: 2063-71. 


\section{LIST OF TABLES}

Table 1 The mineral composition of mineral water of Celldömölk

Table 2 Baseline demographic data and other baseline clinical characteristics of the patients with chronic low back pain by treatment group

Table 3 Statistical analysis of changes over 3 and 15 weeks, compared to baseline; comparison of the nature of changes and of treatment groups in patients with chronic low back pain

Table 4 The mineral composition of mineral water of Gunarasfürdő

Table 5 Baseline demographic data and other baseline clinical characteristics of the patients with osteoarthritis of the hands by treatment group

Table 6 Measured values, changes compared to the baseline, and statistical data of groups at various time points of the study in patients with osteoarthritis of the hands

Table 7 The mineral composition of mineral water of lake Hévíz

Table 8 Baseline demographic data and other baseline clinical characteristics of the patients with osteoarthritis of the knee by treatment group

Table 9 Measured values, changes from baseline, and statistical data of groups at various time points of the study in patients with osteoarthritis of the knee

\section{LIST OF FIGURES}

Figure 1 Disposition of the patients with chronic low back pain

Figure 2 Disposition of the patients with osteoarthritis of the hands

Figure 3 Disposition of the patients with osteoarthritis of the knee 
Appendix 
I. 
II. 
III. 